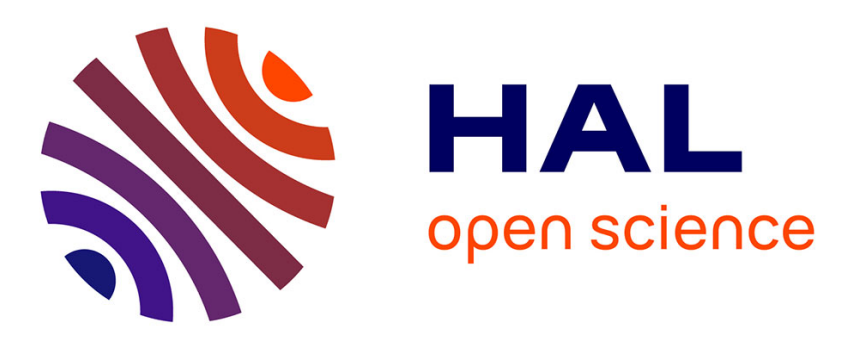

\title{
Pregnancy exposure to atmospheric pollution and meteorological conditions and placental DNA methylation
}

Emilie Abraham, Sophie Rousseaux, Lydiane Agier, Lise Giorgis-Allemand, Jörg Tost, Julien Galineau, Agnès Hulin, Valérie Siroux, Daniel Vaiman, Marie-Aline Charles, et al.

\section{To cite this version:}

Emilie Abraham, Sophie Rousseaux, Lydiane Agier, Lise Giorgis-Allemand, Jörg Tost, et al.. Pregnancy exposure to atmospheric pollution and meteorological conditions and placental DNA methylation. Environment International, 2018, 118, pp.334-347. 10.1016/j.envint.2018.05.007 . hal02325488

\section{HAL Id: hal-02325488 \\ https://hal.science/hal-02325488}

Submitted on 22 Oct 2019

HAL is a multi-disciplinary open access archive for the deposit and dissemination of scientific research documents, whether they are published or not. The documents may come from teaching and research institutions in France or abroad, or from public or private research centers.
L'archive ouverte pluridisciplinaire HAL, est destinée au dépôt et à la diffusion de documents scientifiques de niveau recherche, publiés ou non, émanant des établissements d'enseignement et de recherche français ou étrangers, des laboratoires publics ou privés. 
1 Environ Int. 2018 Sep;118:334-347. doi: 10.1016/j.envint.2018.05.007. Epub 2018 Jun 21.

2 Pregnancy exposure to atmospheric pollution and 3 meteorological conditions and placental DNA methylation

4 Emilie Abraham ${ }^{\mathrm{a}}$, Sophie Rousseaux ${ }^{\mathrm{a}}$, Lydiane Agier $^{\mathrm{a}}$, Lise Giorgis-Allemand ${ }^{\mathrm{a}}$, Jörg 5 Tost $^{\mathrm{b}}$, Julien Galineau ${ }^{\mathrm{c}}$, Agnès Hulin ${ }^{\mathrm{d}}$, Valérie Siroux ${ }^{\mathrm{a}}$, Daniel Vaiman ${ }^{\mathrm{e}}$, Marie-Aline 6 Charles $^{\mathrm{f}}$, Barbara Heude ${ }^{\mathrm{f}}$, Anne Forhan ${ }^{\mathrm{f}}$, Joel Schwartz ${ }^{\mathrm{g}}$, Florent Chuffart ${ }^{\mathrm{a}}$, Ekaterina 7 Flin $^{\mathrm{a}}$, Saadi Khochbin ${ }^{\mathrm{a}}$, Rémy Slama ${ }^{\mathrm{a}}$, Johanna Lepeule ${ }^{\mathrm{a}}$ on behalf of the EDEN mother8 child cohort study group.

9 a Univ. Grenoble Alpes, Inserm, CNRS, IAB, 38000 Grenoble, France; ${ }^{\mathrm{b}}$ Laboratory for 10 Epigenetics and Environment, Centre National de Genotypage, CEA - Institut de Génomique, 11 Evry, France; ${ }^{c}$ Air Lorraine, Nancy, France; ${ }^{\mathrm{d}}$ ATMO Poitou-Charentes, La Rochelle, France; e Genomics, Epigenetics and Physiopathology of Reproduction, Institut Cochin, U1016 13 Inserm -UMR 8104 CNRS - Paris-Descartes University, Paris; ${ }^{\mathrm{f}}$ Inserm U1153, Early Origins 14 of Child Health and Development team, Research Center for Epidemiology and Biostatistics 15 Sorbonne Paris Cité (CRESS), Paris Descartes University, Villejuif, France; ${ }^{\mathrm{g}}$ Department of 16 Environmental Health, Harvard T.H. Chan School of Public Health, Boston, Massachusetts, 17 USA.

\section{Corresponding author:}

19 Johanna Lepeule, IAB - Inserm U1209, Site Santé - Allée des Alpes, 38700 La Tronche.

20 Telephone: +334 76549466 - E-mail: johanna.lepeule@univ-grenoble-alpes.fr 
Competing Financial Interests: The authors declare they have no present or potential competing financial interests.

Funding: This work was made possible thanks to a grant from the Fondation de France (n²012-00031593 and 2012-00031617). This work was also supported by AVIESAN (Alliance nationale pour les sciences de la vie et de la santé, nISP09_2014), the Fonds de Recherche en Santé Respiratoire, the Région Rhône-Alpes, and the National Agency for Research (ANR-13-CESA-0011-02).

Additional supports to SK team projects were from Fondation ARC "Canc'air" project (RAC16042CLA), Plan Cancer (CH7-INS15B66) and Plan Cancer (ASC16012CSA), the “Université Grenoble Alpes” ANR-15-IDEX-02, LIFE and SYMER. The EDEN cohort has been funded by Foundation for Medical Research (FRM), National Agency for Research (ANR), National Institute for Research in Public Health (IRESP: TGIR cohorte santé 2008 program), French Ministry of Health (DGS), French Ministry of Research, Inserm Bone and Joint Diseases National Research (PRO-A) and Human Nutrition National Research Programs, Paris-Sud University, Nestlé, French National Institute for Population Health Surveillance (InVS), French National Institute for Health Education (INPES), the European Union FP7 programmes (FP7/2007-2013, HELIX, ESCAPE, ENRIECO, Medall projects), Diabetes National Research Program (through a collaboration with the French Association of Diabetic Patients (AFD)), French Agency for Environmental Health Safety (now ANSES), Mutuelle Générale de l'Education Nationale (MGEN), French National Agency for Food Security, and the French-speaking association for the study of diabetes and metabolism (ALFEDIAM). Funders had no influence of any kind on analyses or results interpretation. 


\section{ABSTRACT}

Background: In utero air pollution exposure represents a major health threat to the developing foetus. DNA methylation is one of the most well-known molecular determinants of the epigenetic status of cells. Blood DNA methylation has been proven sensitive to air pollutants, but the molecular impact on new-borns has so far received little attention.

Objectives: We investigated whether nitrogen dioxide $\left(\mathrm{NO}_{2}\right)$, particulate matter $\left(\mathrm{PM}_{10}\right)$, temperature and humidity during pregnancy are associated with differences in genome-wide placental DNA methylation levels.

Methods: Whole-genome DNA-methylation was measured using the Illumina's Infinium HumanMethylation450 BeadChip in the placenta of in 668 individuals enrolled in the EDEN cohort. We designed an original strategy using a priori biological information to focus on candidate genes with a specific expression pattern in placenta (active or silent) combined with an agnostic epigenome-wide association study (EWAS). We used robust linear regression to identify CpGs and differentially methylated regions (DMR) associated with each exposure during short- and long-term time-windows.

Results: The candidate genes approach identified nine CpGs mapped to 8 genes associated with prenatal $\mathrm{NO}_{2}, \mathrm{PM}_{10}$ and humidity exposure [false discovery rate $(\mathrm{FDR}) \mathrm{p}<0.05$ ]. Among these, the methylation level of $2 \mathrm{CpGs}$ located on $A D O R A 2 B$ remained significantly associated with $\mathrm{NO}_{2}$ exposure during the $2^{\text {nd }}$ trimester exposure in the EWAS (FDR $\mathrm{p}<0.05$ ). EWAS further revealed associations between exposure and variations of DNA methylation of 4 other CpGs. We further identified 27 DMRs significantly (FDR p<0.05) associated with air pollutants exposure and 13 DMRs with weather conditions exposure.

Conclusions: These findings demonstrate that air pollutants exposure at levels commonly experienced in the European population are associated with placental gene methylation and provide some mechanistic insight into some of the reported effect of air pollutants on pre- 
eclampsia. Indeed, the methylation of $A D O R A 2 B$, a gene whose expression was previously associated with hypoxia and pre-eclampsia, was consistently found here sensitive to atmospheric pollutants. In addition, a number of air pollutants associated DMRs pointed to genes previously implicated in preeclampsia and metabolic syndrome.

Key words: mother-child cohort, placenta, air pollution, epigenetics, temperature, humidity

\section{Introduction}

Despite significant improvements in air quality in past decades, $50 \%$ of the population in 2014 in Europe live in areas that do not meet the World Health Organisation guidelines (World Health Organization, 2006) for particulate matter less than 10 microns $\left(\mathrm{PM}_{10}\right), 85 \%$ for particulate matter less than 2.5 microns $\left(\mathrm{PM}_{2.5}\right)$, and $7 \%$ for nitrogen dioxide $\left(\mathrm{NO}_{2}\right)(\mathrm{Ortiz}$, 2017). Ambient air pollution includes gaseous pollutants, such as nitrogen oxides, sulphur dioxide, ozone, benzene, as well as particulate matter of various sizes, which are a mixture of solid and liquid droplets including black carbon, metals, and polycyclic aromatic hydrocarbons. Air pollutants exposure during pregnancy is a major health threat to children as it can cross the placenta and expose the developing foetus (Valentino et al., 2015; Wick et al., 2010). Exposure to air pollutants during pregnancy has been associated to a range of adverse health outcomes both in the short-term, including low birth weight and preterm birth and in the long term, including infant reduced lung function and neurodevelopmental disorders (Chiu et al., 2016; Clifford et al., 2016; Jedrychowski et al., 2010; Stieb et al., 2012). Air pollution pregnancy exposure is also a threat to the pregnant woman and is likely a risk factor of preeclampsia (M. Pedersen et al., 2014). More recently, high- or low-ambient temperatures have also been suggested to play a role in adverse pregnancy outcomes (Beltran et al., 2014; Giorgis-Allemand et al., 2017; Kloog et al., 2015). 
The placenta plays a key role in foetal programming by supporting both the health of the mother and the development of the foetus. It conveys nutrients and oxygen to the foetus and regulates gas and waste exchanges as well as hormone interactions (Murphy et al., 2006). Alterations in placental physiology and function, potentially driven by epigenetic changes, may impact the health of the future individuals during their childhood as well as into their adulthood. Exposure to chemically and/or physically inappropriate environmental conditions during pregnancy can affect the placental function by modifying its epigenome (Nelissen et al., 2011). Indeed epigenetic mechanisms control the timing and levels of gene expression, by defining the extent of their activation or by maintaining them repressed. Hence in utero environmental exposures could result in epigenetic modifications of the placenta at birth, including changes in the DNA methylation profile. As a transient organ, the placenta may provide a unique record of exposures specifically occurring during pregnancy. While several studies have reported changes in global and gene-specific methylation patterns from adult blood associated with air pollution (Madrigano et al., 2011; Panni et al., 2016), temperature and relative humidity exposure (Bind et al., 2014), the role of maternal exposure to such environmental factors on new-borns DNA methylation patterns has received little attention so far. In cord blood, methylation in mitochondria-related genes was associated with $\mathrm{NO}_{2}$ exposure during pregnancy in a recent meta-analysis (Gruzieva et al., 2017). In placenta, a few studies have linked global DNA methylation and gene candidate methylation to air pollution exposure during pregnancy (Cai et al., 2017; Janssen et al., 2013). However, no study has yet investigated the relationship between exposure to air pollutants and meteorological conditions during pregnancy and placental methylation patterns at a genomewide scale.

We hypothesized that maternal exposure to air pollutants and meteorological conditions could alter the placental function through modifications of DNA methylation. Therefore we 
119 investigated the relationship of air pollutants and meteorological conditions with global DNA

120 methylation and gene-specific methylation in placentas at birth using the Illumina 450k array.

121 In order to identify potentially relevant changes in genomic methylation sites related to

122 environmental exposures, we used two complementary approaches combining a concept-

123 driven analysis with an Epigenome Wide Association Study (EWAS) (Figure 1). The

124 concept-driven analysis is an original strategy relying on the hypothesis that sensitivity to

125 DNA methylation variations induced by environmental factors may depend on the activity of

126 the genomic region considered (Rousseaux et al., 2013). Indeed, a change in the DNA

127 methylation profile affecting a region involved in the epigenetic control of the expression

128 level of a gene actively repressed or activated during pregnancy is more likely to be

129 biologically relevant than a change occurring in another region of the genome. Therefore,

130 based on available expression data in placenta, we identified genes whose expression is either

131 predominant in full-term placenta or undergoes significant variations during placenta

132 development. In addition, using our methylation data, we also established a list of genes with

133 highly methylated CpG-rich promoters. Focussing on these genes with a specific status or 134 pattern of expression in the placenta, enabled us to explore the "basal epigenome dynamics -

135 epigenome response" relationship in the placenta. We then used an agnostic EWAS design, in

136 an attempt to confirm the findings of the concept-driven analysis and to identify new regions

137 associated with maternal air pollutants exposure.

138 Figure 1. Workflow of the study 


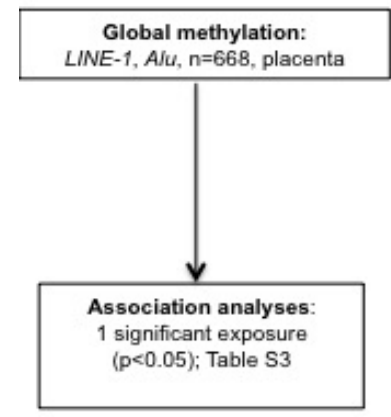

139

140

141

142

143

144 institution "Commission Nationale de l'Informatique et des Libertés" (CNIL). Written

154 consent was obtained from the mother for herself and for the offspring.

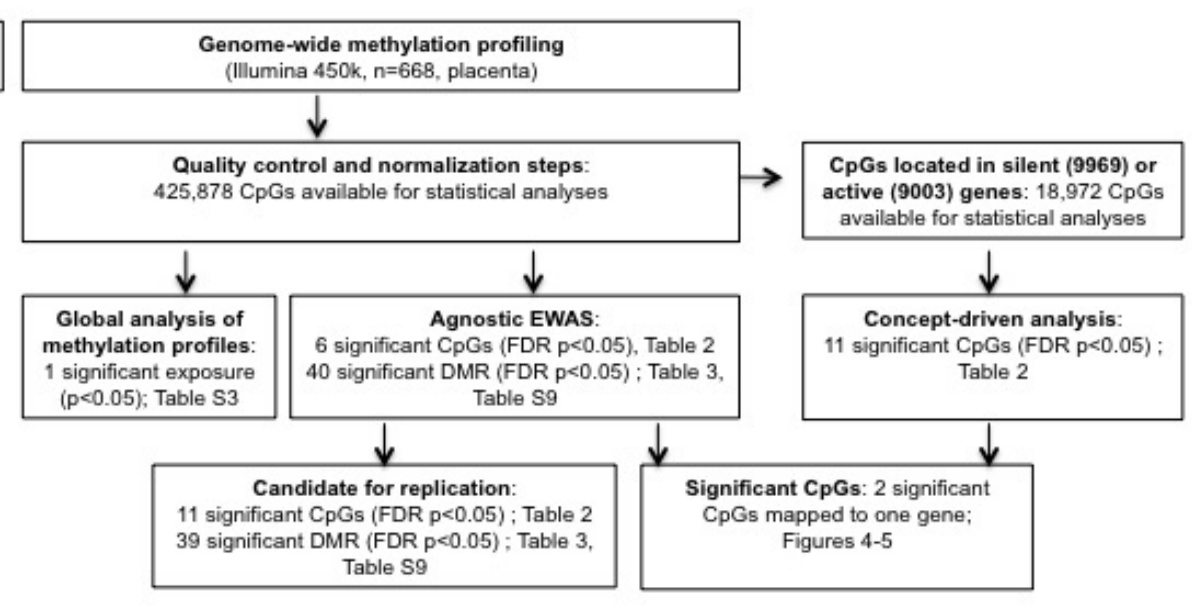

\section{Methods}

\subsection{Study population}

The EDEN mother-child cohort included 2002 pregnant women, mainly Caucasian, enrolled before 24 weeks of gestation in Nancy and Poitiers university hospitals, France, between 2003 and 2006 (Heude et al., 2015). Exclusion criteria were multiple pregnancies, pre-pregnancy diabetes, French illiteracy and planned move outside the region in the following 3 years. Residential addresses, lifestyle, demographic and medical data were collected by questionnaires and interviews during pregnancy and after delivery. Among the 1301 women for whom placenta samples were collected, we focused on 668 women. Placenta samples were collected at delivery by the midwife or the technician of the study using a standardized procedure. Samples of around $5 \mathrm{~mm} \times 5 \mathrm{~mm}$ were carried out in the centre of the placenta on the foetal side and were immediately frozen at $-80^{\circ} \mathrm{C}$. The EDEN cohort received approval from the ethics committee (CCPPRB) of Kremlin Bicêtre and from the French data privacy 
156 DNA from placental samples was extracted using the QIAsymphony instrument (Qiagen,

157 Germany). The DNA methylation analysis was performed by The Centre National de

158 Génotypage (CNG, Evry, France). The DNA samples were plated onto 96-well or 48-well

159 plates. In total, nine plates including 64 chips were used. These plates were analyzed in 4

160 batches. The ratios for sex (boy/girl) and recruitment centre (Poitiers/Nancy) were balanced

161 for each chip. The Illumina's Infinium HumanMethylation450 BeadChip, representing over

162485,000 individual CpG sites, was used to assess levels of methylation in placenta samples

163 following the manufacturer's instructions (Illuminas, San Diego, CA, USA). Raw signals of

164 450K BeadChips were extracted using the GenomeStudio ${ }^{\circledR}$ software (v2011.1. Illumina). The

165 DNA methylation level of each $\mathrm{CpG}$ was calculated as the ratio of the intensity of fluorescent

166 signals of the methylated alleles over the sum of methylated and unmethylated alleles $(\beta$

167 value). All samples passed initial quality control and had on average more than $98 \%$ of valid 168 data points (detection p-value $<0.01$ ). A refined version of the Subset Quantile Normalization

169 (SQN) pipeline (Touleimat and Tost, 2012) including a revised annotation file (Price et al.,

170 2013) was used for data processing, correction and normalization. Intensity values were

171 corrected for potential biases in fluorescent dye intensity and background corrected using the

172 lumi $\mathrm{R}$ package (Du et al., 2008) as implemented in the SQN pipeline. Probes potentially

173 influenced by SNPs underlying the entire sequence of the probe $(+1$ or +2 bases depending

174 on the Infinium probe type) that are present in the EUR population of the 1000 Genome

175 project (http://www.1000genomes.org)) at a frequency of more than 5\% were removed from

176 the analysis. Probes previously reported to map to several genomic regions were removed

177 (Y.-A. Chen et al., 2013). The SQN pipeline uses the intensity signals of high-quality (i.e. low

178 detection p-value) Infinium I probes as "anchors" to estimate a reference distribution of

179 quantiles for probes in a biologically similar context based on the annotation file (Touleimat

180 and Tost, 2012). This reference was then used to estimate a target distribution of quantiles for 
181 InfII probes as a means to provide an accurate normalization of InfI/InfII probes and correct

182 for the shift. SQN is performed for each individual separately. A principal component

183 analysis as well as a hierarchical clustering were applied and showed no overall difference in

184 the methylation patterns across participants samples and control samples, so that a quantile

185 normalization was performed for between sample normalization. After quality control and

186 normalization steps, there were 426,049 CpG sites left. Methylation beta values ranged from 0

187 to 1 . Data points with a detection p-value $>0.01$ were excluded from subsequent analyses. To

188 reduce the influence of potential outliers, we excluded data points below the $25^{\text {th }}$ percentile -

$1893 *$ interquartile ranges or above the $75^{\text {th }}$ percentile $+3 *$ interquartile ranges for each probe,

190 which removed $0.4 \%$ of all methylation beta values across participants. CpGs with more than

$19125 \%$ of missing data were removed, leaving 425,878 CpG sites for statistical analyses.

192 Global methylation was also evaluated by measuring methylation in four $\mathrm{CpG}$ sites of

193 repetitive Alu elements $(A l u)$ and long interspersed nucleotide elements 1 (LINE-1) using a

194 previously published pyrosequencing methylation assay (A. S. Yang et al., 2004). We then

195 used the median percent methylation of the four $\mathrm{CpG}$ sites.

\section{2.3. Cellular composition of placenta samples}

197 Cellular composition of biological samples is a potential confounder in epigenetic

198 epidemiology studies. In the absence of reference methylomes for placental tissue, we used a

199 reference-free method, the RefFreeEWAS package available in R (Houseman et al., 2016), to

200 deconvolute cell-type proportions from DNA methylation array data. The method relies on

201 the identification of latent variables as surrogates for cell-type mixture. From the 10,000 most

202 variable CpGs, we identified the optimal number of cell-types to be 6 . We then used the

$203425,878 \mathrm{CpGs}$ to estimate the proportion of each cell-type per sample. 


\subsection{Identification of genes with specific patterns of expression}

206 We developed an approach relying on the integration of biological knowledge on the 207 "epigenome-expression" relationship in the placenta. We hypothesised that genes and 208 chromatin regions whose activity is controlled by DNA methylation as well as dynamically 209 changing chromatin regions should be more prone to be affected by alterations of DNA 210 methylation following environmental insults. We therefore focused on two categories of 211 genes defined below: genes that are particularly active in the placenta and genes that are silent 212 in the placenta but poised to be activated in response to external stimuli.

213 We defined placenta-predominantly expressed ("active") genes as genes highly expressed in 214 the placenta at the end of pregnancy, and with little or no expression in other tissues. This list 215 was defined through the exploitation of public transcriptomic data 216 (http://www.ncbi.nlm.nih.gov/geo/: GSE3526, GSE18809, GSE7434, GSE9984 studies) in 217 which 575 genes showed a predominant expression in placentas at birth after normal 218 pregnancies. A placenta predominant expression was defined by a mean level of expression 219 value in placenta samples being above a threshold defined as the mean expression values +2 220 standard deviations of a series of 112 adult non-germline/non-placenta tissues of various 221 origins. The pre-treatment of transcriptomic data and the strategy to identify genes with a 222 predominant expression in specific tissue types have been described previously (Rousseaux et 223 al., 2013; Wang et al., 2015). These 575 placenta-predominantly expressed genes 224 corresponded to 9,003 CpGs measured by the Illumina beadchip (Table S1).

225 Placenta DNA methylation-dependent repressed ("silent") genes included genes whose 226 regulatory region is heavily methylated in placenta, based on the assumption that a high level 227 of methylation in CpG-rich regions (or CpG islands) in the regulatory elements of these genes 228 could be associated with a methylation dependent repression. We then hypothesized that these 229 genes could potentially be reactivated upon demethylation. There were 9,969 CpGs located in 
CpG islands (and which were not in the CpGs list corresponding to placenta-predominantly expressed genes) and whose mean methylation level in our dataset was above $80 \%$ (Table S1). Annotation of CpGs was based on information available in the R/Bioconductor package IlluminaHumanMethylation450kanno.ilmn12.hg19, version 0.6.0.

\subsection{Environmental exposures assessment}

$\mathrm{NO}_{2}$ and $\mathrm{PM}_{10}$ hourly concentrations were modelled at the women's home addresses during pregnancy using the quasi-Gaussian Atmospheric Dispersion Modelling System (ADMS) Urban 3.1 (Cambridge Environmental Research Consultants. Cambridge. United Kingdom) (Sellier et al., 2014). The model was implemented with the same methodology for both Poitiers and Nancy and provides hourly estimates on a 40x40 meters grid. Mean daily ambient temperature $\left(\mathrm{T}\right.$, in $\left.{ }^{\circ} \mathrm{C}\right)$ and relative humidity $(\mathrm{RH}$, in $\%)$ were obtained from the monitors of the French weather network Météo France. For each woman, the nearest monitor to her home address was used. Because the most biologically relevant time period for the effect of air pollution and weather conditions on methylation is unknown, we considered different exposure windows throughout pregnancy over which we averaged levels of $\mathrm{NO}_{2}$, $\mathrm{PM}_{10}$, T and RH: day 1, 2 and 3 before delivery, one week before delivery, one month before delivery, each trimester of pregnancy and the whole pregnancy.

\subsection{Statistical analyses}

\subsubsection{Global methylation}

We examined the impact of environmental exposures on the overall methylation level across the entire genome using two approaches, one relying on repetitive elements Alu and LINE-1 
and the other relying on the global profile of methylation levels estimated for the 425,878 254 CpGs.

255 Association of $A l u$ and LINE-1 methylation levels with air pollutants and meteorological 256 exposures were investigated using robust linear regression, which accounts for potential 257 outliers and heteroscedasticity in the data. We adjusted for the following a priori selected 258 covariates: child sex, parity $(0,1, \geq 2$ children $)$, maternal age at end of education $(\leq 18,19-20$, $25921-22,23-24, \geq 25$ years), season of conception, study centre (Poitiers and Nancy), maternal 260 body mass index before pregnancy (continuous), maternal age at delivery (linear and 261 quadratic terms), maternal smoking during pregnancy (continuous) and gestational duration 262 (linear and quadratic terms). We additionally adjusted for technical factors related to the 263 methylation measurements (batch, plate and chip) and for the estimated cell-type proportions. 264 Meteorological exposures - temperature and humidity (restricted cubic splines) - were 265 investigated simultaneously. Each air pollutant was studied separately and further adjusted for 266 meteorological exposures (temperature and humidity, with restricted cubic splines).

267 Complementary to the repetitive elements analysis, we conducted a global analysis of 268 methylation profiles (GAMP). This method, described by Zhao et al. (2015), allows to test 269 whether exposure changes the overall profile or distribution of $\mathrm{CpG}$ measurements of the 270 participants instead of examining the effect on individual CpGs. Each individual's methylation 271 profile was characterized by approximating the density function and the cumulative 272 distribution function of the methylation distribution using B-splines basis functions. The B273 spline coefficients were then used to represent each individual overall methylation 274 distribution. A variance component score test from the kernel machine framework, which 275 naturally accommodates the correlation between B-spline coefficients, was computed to test 276 the association of B-spline coefficients with each exposure of interest (temperature, humidity, $277 \mathrm{NO}_{2}, \mathrm{PM}_{10}$ ) adjusted for confounders. Meteorological exposures were investigated 
278 simultaneously. Each air pollutant was studied separately in models further adjusted for

279 meteorological exposures (temperature and humidity).

\subsubsection{Methylation at specific loci}

282 We studied the association between environmental exposures $\left(\mathrm{NO}_{2}, \mathrm{PM}_{10}\right.$, temperature, 283 humidity) and CpG-specific methylation level using a robust linear regression model. We 284 applied the same approach described for global methylation analysis by testing: the 285 simultaneous effect of meteorological conditions (temperature and humidity) (1); the effect of each air pollutant adjusted for meteorological conditions (temperature and humidity) (2) using the following models:

(1) $Y_{i j}=\beta_{0}+f\left(\beta_{1} \cdot\right.$ Temperature $\left._{i}\right)+f\left(\beta_{2} \cdot\right.$ Humidity $\left._{i}\right)+\beta_{z}^{T} Z_{i}+\varepsilon_{i j}$.

(2) $\mathrm{Y}_{\mathrm{ij}}=\beta_{0}+\beta_{1}$ Pollutant $_{\mathrm{i}}+\mathrm{f}\left(\beta_{2}\right.$. Temperature $\left._{\mathrm{i}}\right)+\mathrm{f}\left(\beta_{3}\right.$. Humidity $\left._{\mathrm{i}}\right)+\beta_{\mathrm{z}}^{\mathrm{T}} \mathrm{Z}_{\mathrm{i}}+\varepsilon_{\mathrm{ij}}$.

Where $\mathrm{Y}_{\mathrm{ij}}$ is the methylation measurement for $\mathrm{CpG} j$ in subject $i$, $f\left(\beta_{2}\right.$. Temperature $)$ and $f\left(\beta_{2}\right.$. Humidity $\left.i\right)$ are restricted cubic spline functions of temperature and humidity, $Z_{i}$ is the set of adjustment factors similar to the one used for the global methylation analysis and $\varepsilon_{i j}$ is the random error. Each exposure window was tested in a separate model. Multiple testing was accounted for by applying a Benjamini and Hochberg False Discovery Rate (FDR) correction to the p-values that were obtained (Benjamini and Hochberg, 1995). The FDR corrected p-values were calculated for the 18,972 CpGs included in the active and silent genes lists for the concept-driven analysis and for the $425,878 \mathrm{CpGs}$ for the agnostic EWAS. An FDR-corrected p-value $<0.05$ was considered statistically significant. For all significant CpGs (FDR-corrected p-value <0.05), we further tested whether the association with the exposures differed by child sex by adding an interaction term in the 
301

302

303

304

305

306

307

308

309

310

311

312

313

314

315

316

317

318

319

320

321 322

model. The genomic inflation factor (lambda) has been widely used in GWAS to assess inflation/deflation of p-values (Devlin et al., 2001). A recent study demonstrated that the Bayesian Inflation Factor (BIF) was a more relevant approach for EWAS (van Iterson et al., 2017). We computed the lambda and BIF for both the concept-driven analysis and the agnostic EWAS.

\subsubsection{Region-based analysis}

To identify Differentially Methylated Regions (DMRs) in our data, we used Comb-p, a method relying on the Stouffer-Liptak-Kechris correction that combines specific CpG pvalues using sliding windows and accounting for correlation between $\mathrm{CpGs}$ (B. S. Pedersen et al., 2012). DMR p-values were adjusted for multiple testing by Šidák correction (Šidák, 1967). Significant DMRs (p-value<0.05) included at least 2 probes (p-value $<0.001$ ) at a maximum distance of $500 \mathrm{bp}$. All analyses were performed using the statistical software R (version 3.0.1) and Python (version 2.7.14).

\section{Results}

\subsection{Population characteristics and environmental factors}

On average $( \pm \mathrm{SD})$, the participating mothers were $29( \pm 5.1)$ years old, with a pre-pregnancy BMI of $22.9( \pm 4.2) \mathrm{kg} / \mathrm{m}^{2}$ (Table 1$)$. Mean gestational duration was $40( \pm 1.7)$ weeks and 32 babies $(5 \%)$ were born preterm ( $<37$ gestational weeks).

Table 1. Characteristics of the EDEN study population $(n=668)$ and environmental exposures over the whole pregnancy period.

\begin{tabular}{lcrrrrr}
\hline & mean \pm SE & n $(\%)$ & \multicolumn{4}{c}{ Median pregnancy levels } \\
\hline Characteristics & All & \multicolumn{1}{c}{ T } & RH & NO $_{2}$ & PM $_{\mathbf{1 0}}$ \\
\hline Center & & & & & & \\
$\quad$ Poitiers & 287 & $(43)$ & 12.2 & 77.3 & 12.2 & 15.6 \\
$\quad$ Nancy & $381(57)$ & 9.8 & 77.2 & 23.4 & 23.4 \\
Sex of offspring & & & & & &
\end{tabular}




\section{Page 15 of 36}

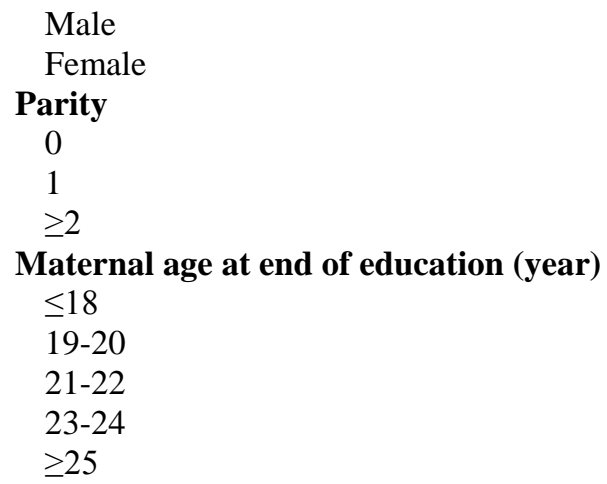

Season of conception

January - March

April - June

July - September

October - December

$\operatorname{BMI}\left(\mathrm{kg} / \mathrm{m}^{2}\right)$

Maternal age (year)

Maternal smoking ${ }^{\mathrm{a}}$

Gestational duration (weeks)

$\begin{array}{rrrrrr}349 & (52) & 10.7 & 77.4 & 17.1 & 20.6 \\ 319 & (48) & 11.1 & 76.8 & 17.4 & 21.5 \\ 301 & (45) & 11.3 & 77.3 & 17.0 & 20.8 \\ 252 & (38) & 10.5 & 77.4 & 17.3 & 21.2 \\ 115 & (17) & 11.0 & 76.9 & 17.4 & 21.0 \\ & & & & & \\ 132 & (20) & 10.9 & 77.2 & 17.4 & 20.7 \\ 114 & (17) & 11.1 & 77.5 & 15.8 & 17.5 \\ 151 & (23) & 10.9 & 77.1 & 16.9 & 21.3 \\ 145 & (22) & 11.0 & 76.7 & 18.2 & 21.3 \\ 126 & (19) & 10.8 & 77.8 & 18.8 & 21.4 \\ & & & & & \\ 143 & (21) & 13.5 & 73.8 & 14.6 & 17.2 \\ 153 & (23) & 12.3 & 77.3 & 18.6 & 21.8 \\ 189 & (28) & 8.7 & 80.1 & 19.3 & 22.0 \\ 183 & (27) & 10.1 & 76.7 & 16.9 & 20.5\end{array}$

$22.9 \pm 4.2$

$29.0 \pm 5.1$

$1.7 \pm 3.5$

$39.8 \pm 1.7$

$323 \mathrm{~T}=$ Temperature $\left({ }^{\circ} \mathrm{C}\right) . \mathrm{RH}=$ Relative humidity $(\%) . \mathrm{NO}_{2}=$ Nitrogen dioxide $\left(\mu \mathrm{g} / \mathrm{m}^{3}\right) . \mathrm{PM}_{10}=$ Particulate matter 324 smaller than $10 \mu \mathrm{m}\left(\mu \mathrm{g} / \mathrm{m}^{3}\right)$. BMI= pre-pregnancy Body Mass Index.

325 average number of cigarette per day during pregnancy

326

327 The longer the exposure window was, the less variable was the exposure level (Figure 2).

328 Mean pregnancy levels were $19( \pm 7.7) \mu \mathrm{g} / \mathrm{m}^{3}$ for $\mathrm{NO}_{2}$ and $20( \pm 4.5) \mu \mathrm{g} / \mathrm{m}^{3}$ for $\mathrm{PM}_{10}$. 
Figure 2. Environmental exposure across time window (d1, 2, 3 = day 1, 2, 3 before delivery; $\mathrm{w}=$ week before delivery; $\mathrm{m}=$ month before delivery; $\mathrm{t} 1,2,3=\operatorname{trimester} 1,2,3$ and $\mathrm{P}=$

331 whole pregnancy).
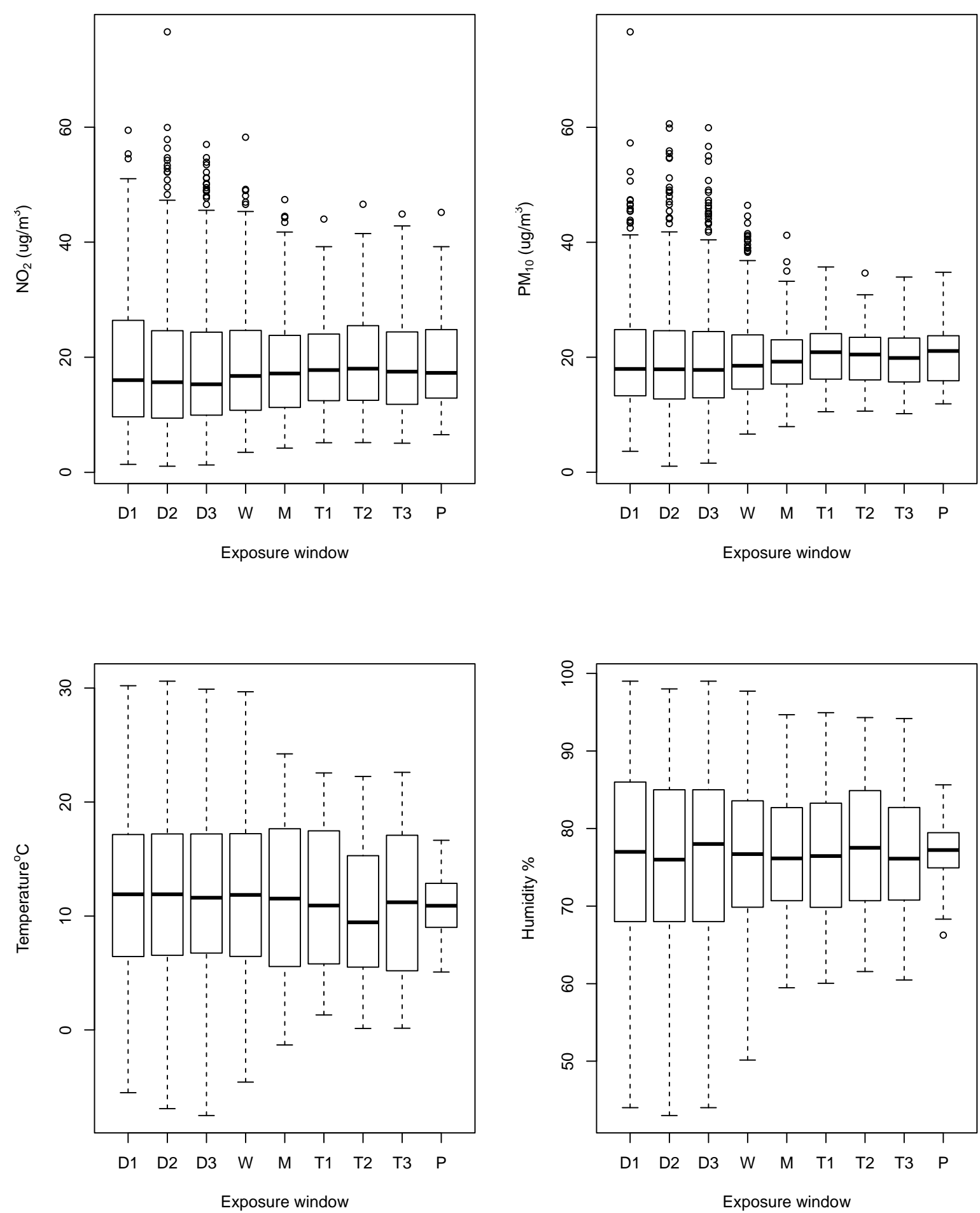

$333 \mathrm{NO}_{2}$ and $\mathrm{PM}_{10}$ levels were highly correlated (range, 0.73 to 0.84 depending on averaging 334 period, see Table S2). For each air pollutant, trimester-specific levels were strongly and 
positively correlated (correlation ranged from 0.52 to 0.78 for $\mathrm{NO}_{2}$ and from 0.79 to 0.86 for $\left.\mathrm{PM}_{10}\right)$. Average temperature exposure during pregnancy varied from $5{ }^{\circ} \mathrm{C}$ minimum to $16{ }^{\circ} \mathrm{C}$ maximum while relative humidity varied from $66 \%$ minimum to $86 \%$ maximum.

Temperature and humidity were strongly and negatively correlated (range between -0.71 and 0.80, depending on averaging period, see Table S2). As for correlation between air pollutants and meteorological conditions, $\mathrm{NO}_{2}$ levels were moderately correlated with temperature and humidity $(|\mathrm{r}|=0.15$ to 0.61$)$ and $\mathrm{PM}_{10}$ levels were weakly correlated with temperature and humidity $(|\mathrm{r}|=0.04$ to 0.34$)$.

\subsection{Global DNA methylation}

Average methylation level was $16.2( \pm 1.0)$ for Alu and $26.1( \pm 1.9)$ for LINE-1. The distribution of average methylation level by $\mathrm{CpG}$ site was bimodal, with a peak around 0.025 and another around 0.925 (Figure S1). Highest variability in methylation levels was observed for moderately methylated $\mathrm{CpG}$ sites (see Figure $\mathrm{S} 2$ ). $\mathrm{PM}_{10}$ exposure the day before birth was positively associated with Alu methylation with a 0.08 regression coefficient ( $\mathrm{p}$-value $=0.01$ ) (Table S3). Temperature exposure during the $1^{\text {st }}$ trimester of pregnancy was significantly associated with the density of methylation distribution ( $\mathrm{p}$-value=0.03). However, analyses of Alu and LINE-1 as well as the global analysis of methylation profiles mainly yielded not significant differences with p-values higher than 0.05 (Table S3).

\subsection{Concept-driven approach: silent and active genes in placenta}

Among the list of placenta-predominantly expressed genes ("active genes"), 3 CpGs mapping to 3 genes, whose average methylation levels varied between 0.03 and 0.58 , were significantly associated with $\mathrm{NO}_{2}$ exposure (FDR p-values $<0.05$, Table 2). Two of these 3 
CpGs are located in the body of $A D O R A 2 B$, encoding the Adenosine A2B Receptor, one is in a region shared by the promoter regions of two genes, PXT1 (Peroxisomal testis specific 1) and KCTD20 (potassium channel teramerization domain containing 20). The methylation levels of the two CpGs of $A D O R A 2 B$ decreased on average with higher exposure to $\mathrm{NO}_{2}$ during the $1^{\text {st }}$ or $2^{\text {nd }}$ trimester or during the whole pregnancy. Conversely, the methylation of the $\mathrm{CpG}$ located in the promoter of the PXT1 and KCTD2O genes was positively associated with $\mathrm{NO}_{2}$ exposure during both the $2^{\text {nd }}$ trimester and the whole pregnancy. Regarding exposure to $\mathrm{PM}_{10}$, one $\mathrm{CpG}$ located in the promoter of $S L C 44 A 5 B$ (solute carrier family 44 member 5) gene was positively associated with exposure the month before birth and another CpG located in the body of $K Y N U$ (kynureninase) was negatively associated with exposure 3 days before birth. No significant association with methylation was found for temperature and humidity levels (lowest FDR p-values, 1.00, 1.00, respectively).

Among the placenta DNA methylation-dependent repressed genes ("silent genes"), one CpG, located in the body of the CAPN1O (Calcium-Activated Neutral Proteinase 10) gene, was positively associated with $\mathrm{NO}_{2}$ exposure during the $3^{\text {rd }}$ trimester. Exposure to $\mathrm{PM}_{10}$ the month before birth was negatively associated with mean methylation of one $\mathrm{CpG}$ located in the body of $T U B G C P 2$ (tubulin gamma complex associated protein 2) and was positively associated with mean methylation of two CpGs, one located in the body of TGM6 (transglutaminase 6) and another located in the body of ADCK5 (aarF domain containing kinase 5). Regarding exposure to meteorological conditions, no significant associations with methylation of active genes were found (lowest FDR p-values, 1.00 for temperature and humidity).

The p-value distribution of the $18,972 \mathrm{CpGs}$ included in the concept-driven analysis was close to the theoretical distribution as indicated by the BIF values (range from 0.95 to 1.1 ) which were substantially smaller compared to the lambda values (figures S3-S6). 
Table 2. CpGs associated (FDR p < 0.05) with prenatal exposure to air pollutants or meteorological conditions

\begin{tabular}{|c|c|c|c|c|c|c|c|c|c|c|}
\hline \multirow{2}{*}{ Exposure } & \multirow[b]{2}{*}{ CpG } & \multirow[b]{2}{*}{ Chr } & \multirow{2}{*}{$\begin{array}{l}\text { Position } \\
\text { (built 37) }\end{array}$} & \multirow[b]{2}{*}{ Gene } & \multirow{2}{*}{$\begin{array}{l}\text { Location } \\
\text { in gene }\end{array}$} & \multirow{2}{*}{$\begin{array}{c}\text { Location } \\
\text { of CpG }\end{array}$} & \multirow[b]{2}{*}{$\boldsymbol{\beta}^{\mathrm{a}}$} & \multicolumn{2}{|c|}{ FDR p-value } & \multirow{2}{*}{$\begin{array}{c}\text { Mean } \\
\text { methylation } \\
\text { level (SE) }\end{array}$} \\
\hline & & & & & & & & candidate & EWAS & \\
\hline \multirow{2}{*}{\multicolumn{11}{|c|}{$\begin{array}{l}\text { CpGs located in placenta-predominantly expressed genes }(n=9,003 \text { sites }) \\
\mathbf{N O}_{2}\end{array}$}} \\
\hline & & & & & & & & & & \\
\hline \multirow[t]{3}{*}{ Pregnancy } & $\operatorname{cg} 10984505$ & chr6 & 36410951 & PXT1;KCTD20 & TSS1500;5'UTR & Island & 0.002 & 0.04 & & $0.031(0.006)$ \\
\hline & $\operatorname{cg} 17580614$ & $\operatorname{chr} 17$ & 15849512 & ADORA2B & Body & Island & -0.042 & $<10^{-3}$ & 0.02 & $0.586(0.138)$ \\
\hline & $\operatorname{cg} 07563400$ & $\operatorname{chr} 17$ & 15849556 & ADORA2B & Body & S_Shore & -0.045 & $<10^{-3}$ & & $0.343(0.125)$ \\
\hline \multirow[t]{2}{*}{ Trimester 1} & $\operatorname{cg} 17580614$ & $\operatorname{chr} 17$ & 15849512 & ADORA2B & Body & Island & -0.037 & $<10^{-3}$ & & $0.586(0.138)$ \\
\hline & $\operatorname{cg} 07563400$ & $\operatorname{chr} 17$ & 15849556 & ADORA2B & Body & S_Shore & -0.042 & $<10^{-3}$ & & $0.343(0.125)$ \\
\hline \multirow[t]{3}{*}{ Trimester 2} & $\operatorname{cg} 10984505$ & chr6 & 36410951 & PXT1;KCTD20 & TSS1500;5'UTR & Island & 0.002 & 0.02 & & $0.031(0.006)$ \\
\hline & $\operatorname{cg} 17580614$ & $\operatorname{chr} 17$ & 15849512 & ADORA2B & Body & Island & -0.044 & $<10^{-4}$ & $<10^{-3}$ & $0.586(0.138)$ \\
\hline & $\operatorname{cg} 07563400$ & $\operatorname{chr} 17$ & 15849556 & ADORA2B & Body & S_Shore & -0.047 & $<10^{-4}$ & $<10^{-3}$ & $0.343(0.125)$ \\
\hline \multicolumn{11}{|l|}{$\mathbf{P M}_{10}$} \\
\hline Month before birth & $\operatorname{cg} 12659128$ & $\operatorname{chr} 1$ & 76078176 & SLC44A5 & TSS1500 & N_Shelf & 0.037 & 0.03 & & $0.587(0.070)$ \\
\hline Day 3 before birth & $\operatorname{cg} 04112100$ & chr2 & 143701758 & KYNU & Body & OpenSea & -0.012 & 0.04 & & $0.257(0.068)$ \\
\hline \multicolumn{11}{|c|}{ CpGs located in methylation-dependent repressed genes list $(n=9,969$ sites) } \\
\hline \multicolumn{11}{|l|}{$\mathrm{NO}_{2}$} \\
\hline Trimester 3 & $\operatorname{cg} 01712700$ & $\operatorname{chr} 2$ & 241535695 & CAPN10 & Body & Island & -0.004 & 0.02 & & $0.948(0.013)$ \\
\hline \multicolumn{11}{|c|}{ 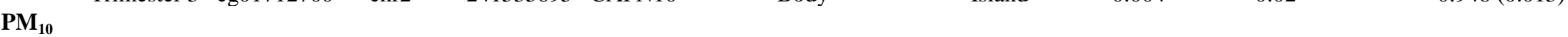 } \\
\hline \multirow[t]{3}{*}{ Month before birth } & $\operatorname{cg} 23075260$ & chr8 & 145617435 & ADCK5 & Body & Island & 0.018 & 0.03 & & $0.878(0.034)$ \\
\hline & $\operatorname{cg} 05142592$ & $\operatorname{chr} 10$ & 135097800 & TUBGCP2 & Body & Island & -0.008 & 0.03 & & $0.953(0.018)$ \\
\hline & $\operatorname{cg} 06967014$ & chr20 & 2384240 & TGM6 & Body & Island & 0.007 & 0.03 & & $0.924(0.015)$ \\
\hline \multicolumn{11}{|c|}{$\begin{array}{l}\text { CpGs not in active and silent placenta genes list (i.e. EWAS approach) } \\
\mathbf{N O}_{2}\end{array}$} \\
\hline Pregnancy & $\operatorname{cg} 20491726$ & chr2 & 242820622 & & & N_Shelf & 0.015 & & 0.02 & $0.715(0.051)$ \\
\hline Trimester 2 & cg20491726 & $\mathrm{chr} 2$ & 242820622 & & & N_Shelf & 0.015 & & 0.02 & $0.715(0.051)$ \\
\hline \multicolumn{11}{|l|}{$\mathbf{P M}_{10}$} \\
\hline Trimester 1 & $\operatorname{cg} 03215416$ & $\operatorname{chr} 8$ & 18823341 & PSD3 & Body & OpenSea & -0.020 & & 0.03 & $0.913(0.024)$ \\
\hline \multicolumn{11}{|c|}{ Humidity } \\
\hline Trimester 2 & $\operatorname{cg} 16917193$ & $\operatorname{chr} 12$ & 54089295 & & & Island & & & $0.04^{\mathrm{b}}$ & $0.104(0.114)$ \\
\hline Month before birth & $\operatorname{cg} 16075020$ & chr19 & 12606183 & ZNF709 & 5'UTR & Island & & & $<10^{-3 \mathrm{~b}}$ & $0.063(0.077)$ \\
\hline
\end{tabular}

$384 \mathrm{NO}_{2}=$ Nitrogen dioxide $\left(\mu \mathrm{g} / \mathrm{m}^{3}\right) . \mathrm{PM}_{10}=$ Particulate matter smaller than $10 \mu \mathrm{m}\left(\mu \mathrm{g} / \mathrm{m}^{3}\right)$.

$385{ }^{\mathrm{a}}$ Results per 10 units increase in prenatal exposure.

$386{ }^{\mathrm{b}} \mathrm{p}$-value of the spline 


\subsection{Agnostic approach: EWAS examining each CpG}

388 When we independently tested the adjusted effect of exposures on each of the 425,878 CpGs, six 389 showed significantly different methylation levels (Table 2). Among these, two CpGs had also been 390 identified in the concept-driven analysis: $\operatorname{cg} 07563400$ and $\operatorname{cg} 17580614$, both located in ADORA2B, 391 remained significantly associated with $\mathrm{NO}_{2}$ exposure during the $2^{\text {nd }}$ trimester of pregnancy after the 392 genome-wide FDR correction of p-values (Table 2; Figure 3). Other CpGs identified as 393 significantly associated with environmental exposures in the concept-driven approach did not 394 achieve genome-wide statistical significance in the EWAS, but all except one of them $(\operatorname{cg} 05142592$ 395 on gene TUBGCP2) were still in the top $20 \mathrm{CpGs}$ with the lowest p-values for association with 396 exposure (see Table S4 to S7).

The EWAS also revealed four new CpGs (not included in the concept-driven list of candidates) whose average methylation was significantly (FDR p-value $<0.05$ ) associated with humidity, $\mathrm{NO}_{2}$ and $\mathrm{PM}_{10}$ exposure (Table 2). One $\mathrm{CpG}$ (cg20491726), mapped to a non genic region, was 400 significantly associated with a $10 \mu \mathrm{g} / \mathrm{m}^{3}$ increase in $\mathrm{NO}_{2}$ exposure during both the second trimester $401(\beta=0.015$ FDR $p=0.02)$ and the whole pregnancy $(\beta=0.015$ FDR $p=0.02)$. Another CpG mapped to PSD3 (pleckstrin and Sec7 domain containing 3) was negatively associated with $\mathrm{PM}_{10}$ during the $1^{\text {st }}$ 403 trimester of pregnancy (Table 3). Two CpGs, one in the non genic region and one mapped to 404 ZNF709 (zinc finger protein 709), were non-linearly associated with humidity in the $2^{\text {nd }}$ trimester of 405 pregnancy and in the month before birth, respectively (Figure S7). The p-value distribution of the 406 425,878 CpGs was close to the theoretical distribution as indicated by the BIF values (range from 0.96 to 1.15 ) (Figure S8 to S11).

Although interaction terms with sex were significant for two CpGs (cg06967014, cg16917193), the 409 effect estimates (Table 8) and dose-response relationship (Figure S7) did not appear substantially 410 different between boys and girls. 
Figure 3. Manhattan plots of p-values showing the association between environmental exposure $\left(\mathrm{NO}_{2}(\mathrm{~A}, \mathrm{~B}), \mathrm{PM}_{10}(\mathrm{C})\right.$, and humidity (D, E)) and 425,878 CpGs methylation using the agnostic EWAS. Each dot corresponds to the p-value of a $\mathrm{CpG}$ site and the horizontal lines indicates the

415 level of statistical significance (FDR $\mathrm{p}<0.05)$.
A) $\mathrm{NO}_{2}$ exposure in pregnancy
B) $\mathrm{NO}_{2}$ exposure in trimester 2
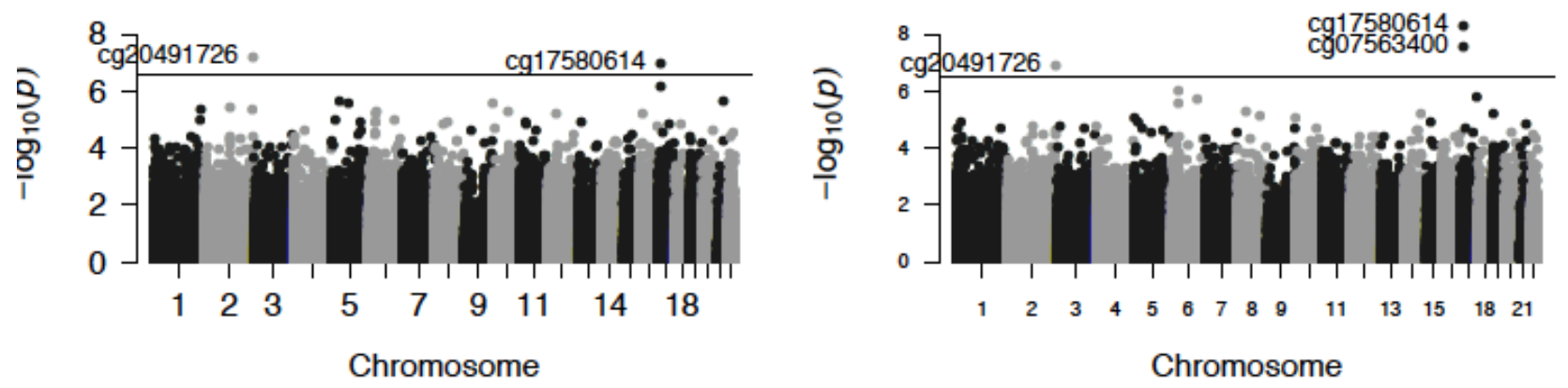

C) $\mathrm{PM}_{10}$ exposure in trimester 1

D) Humidity during trimester 2
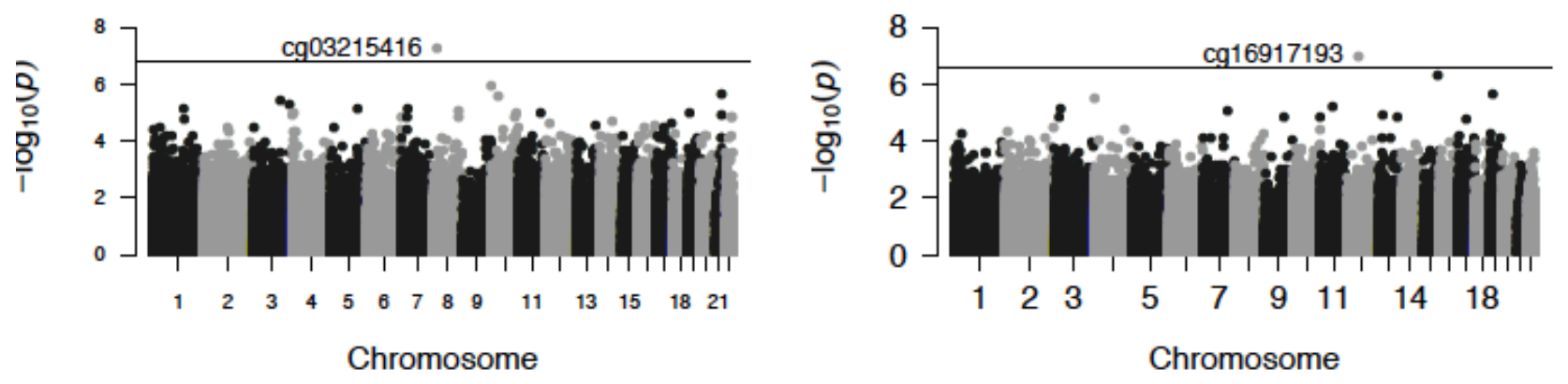

E) Humidity during month before birth

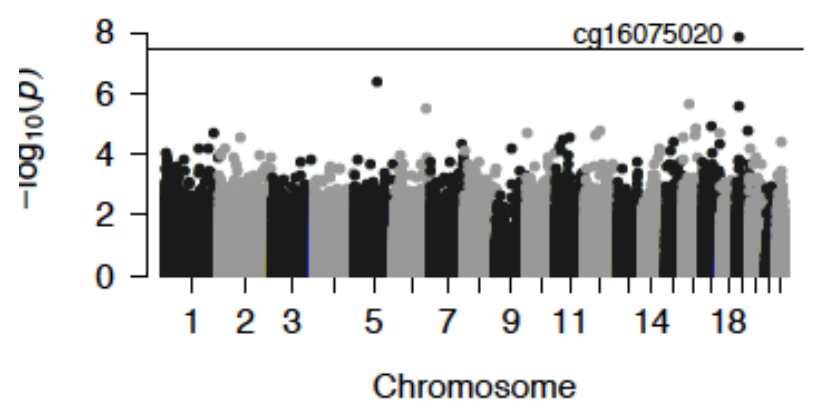

\subsection{Regional analysis}

418 Our regional analysis identified 27 DMRs significantly (Sidak-corrected P-value<0.05) associated 419 with air pollutants exposure and 13 DMRs with weather conditions exposure (Table 3, Table S9).

420 The ADORA2B-associated DMR was identified for the three trimesters and the whole pregnancy;

421 the DMR included the two CpGs previously identified in the site-specific analyses. Among genes 422 highly represented in the identified DMRs, several CpGs located in the FAM38A gene were 
423 negatively associated with $\mathrm{NO}_{2}$ exposure in each trimester, last month and pregnancy. The 424 FAM124B-associated DMR was hypomethylated across the $7 \mathrm{CpGs}$ included in women with 425 increased exposure to $\mathrm{NO}_{2}$ or $\mathrm{PM}_{10}$, especially towards the end of pregnancy. $\mathrm{NO}_{2}$ exposure, 426 especially towards the end of pregnancy ( $3^{\text {rd }}$ trimester and last month) was negatively associated 427 with two DMRs located in HSP9OAAl and LOC254559 and positively associated with two DMRs 428 located in LZTFL1, and P2RX4. The top-ranked DMRs in terms of number of CpGs included were 429 located in CD81 (13 CpGs) and in a non-genic region on chromosome 6 (15 CpGs). 
432 Table 3. Regions identified using the Comb-P method as differentially methylated in the placenta in 433 association with air pollutants exposure in pregnancy.

\begin{tabular}{|c|c|c|c|c|c|c|c|}
\hline Gene $^{1}$ & Hg19 & Exposure & $\begin{array}{l}\text { Time } \\
\text { window }\end{array}$ & $\begin{array}{l}\text { No. of } \\
\text { probes }\end{array}$ & $\begin{array}{l}\text { Slk } \\
\text { p-value }\end{array}$ & $\begin{array}{l}\text { Sidak } \\
\text { p-value }\end{array}$ & $\begin{array}{l}\text { Directic } \\
\text { of effec }\end{array}$ \\
\hline \multirow[t]{4}{*}{ ADORA2B } & \multirow[t]{4}{*}{ chr17:15849512-15849557 } & $\mathrm{NO}_{2}$ & $\mathrm{p}$ & 2 & $4.93 \mathrm{E}-12$ & $4.67 \mathrm{E}-08$ & - \\
\hline & & $\mathrm{NO}_{2}$ & $\mathrm{t} 1$ & 2 & $9.18 \mathrm{E}-12$ & 8.69E-08 & - \\
\hline & & $\mathrm{NO}_{2}$ & $\mathrm{t} 2$ & 2 & $1.29 \mathrm{E}-14$ & $1.22 \mathrm{E}-10$ & - \\
\hline & & $\mathrm{NO}_{2}$ & $\mathrm{t} 3$ & 2 & 3.29E-09 & $3.11 \mathrm{E}-05$ & - \\
\hline \multirow[t]{2}{*}{ ANKRD45 } & \multirow[t]{2}{*}{ chr1:173639044-173639136 } & $\mathrm{NO}_{2}$ & $\mathrm{~m}$ & 4 & $1.61 \mathrm{E}-08$ & $7.43 \mathrm{E}-05$ & - \\
\hline & & pm10 & $\mathrm{m}$ & 4 & 2.99E-08 & $1.39 \mathrm{E}-04$ & - \\
\hline B3GALT4 & chr6:33245717-33245805 & $\mathrm{NO}_{2}$ & $\mathrm{p}$ & 6 & $1.04 \mathrm{E}-05$ & $4.90 \mathrm{E}-02$ & - \\
\hline C1orf86;LOC100128003 & chr1:2125049-2125244 & $\mathrm{NO}_{2}$ & $\mathrm{p}$ & 7 & 7.43E-08 & $1.62 \mathrm{E}-04$ & - \\
\hline C22orf9 & chr22:45608345-45608517 & $\mathrm{PM}_{10}$ & $\mathrm{~d} 2$ & 7 & 4.92E-08 & $1.22 \mathrm{E}-04$ & + \\
\hline CD81 & $\operatorname{chr11:2397486-2397832}$ & $\mathrm{PM}_{10}$ & $\mathrm{~d} 1$ & 13 & $1.37 \mathrm{E}-16$ & $1.37 \mathrm{E}-13$ & + \\
\hline DAXX & chr6:33288180-33288373 & $\mathrm{PM}_{10}$ & $\mathrm{~d} 1$ & 6 & $1.41 \mathrm{E}-10$ & $3.10 \mathrm{E}-07$ & - \\
\hline \multirow[t]{4}{*}{ FAM124B } & \multirow[t]{4}{*}{ chr2:225266656-225266881 } & $\mathrm{NO}_{2}$ & $\mathrm{p}$ & 7 & $1.41 \mathrm{E}-08$ & $2.67 \mathrm{E}-05$ & - \\
\hline & & $\mathrm{NO}_{2}$ & $\mathrm{t} 3$ & 7 & $6.55 \mathrm{E}-11$ & $1.24 \mathrm{E}-07$ & - \\
\hline & & $\mathrm{NO}_{2}$ & $\mathrm{~m}$ & 7 & 7.62E-10 & $1.44 \mathrm{E}-06$ & - \\
\hline & & $\mathrm{PM}_{10}$ & $\mathrm{t} 3$ & 7 & $4.80 \mathrm{E}-11$ & $9.09 \mathrm{E}-08$ & - \\
\hline \multirow[t]{2}{*}{ FAM38A } & \multirow[t]{2}{*}{ chr16:88832476-88832573 } & $\mathrm{NO}_{2}$ & $\mathrm{t} 3$ & 4 & $1.05 \mathrm{E}-08$ & $4.62 \mathrm{E}-05$ & - \\
\hline & & $\mathrm{NO}_{2}$ & $\mathrm{~m}$ & 4 & $1.51 \mathrm{E}-09$ & $6.63 \mathrm{E}-06$ & - \\
\hline \multirow[t]{2}{*}{ FAM38A } & \multirow[t]{2}{*}{ chr16:88832476-88832701 } & $\mathrm{NO}_{2}$ & $\mathrm{p}$ & 6 & $1.16 \mathrm{E}-09$ & $2.20 \mathrm{E}-06$ & - \\
\hline & & $\mathrm{NO}_{2}$ & $\mathrm{t} 1$ & 6 & $6.15 \mathrm{E}-11$ & $1.16 \mathrm{E}-07$ & - \\
\hline FAM38A & chr16:88832532-88832573 & $\mathrm{NO}_{2}$ & $\mathrm{t} 2$ & 2 & $4.61 \mathrm{E}-07$ & $4.78 \mathrm{E}-03$ & - \\
\hline GNAS;GNASAS & chr20:57426240-57426275 & $\mathrm{NO}_{2}$ & $\mathrm{p}$ & 3 & $1.64 \mathrm{E}-07$ & $1.99 \mathrm{E}-03$ & + \\
\hline GP1BB;SEPT5 & chr22:19710880-19711052 & $\mathrm{PM}_{10}$ & $\mathrm{~d} 2$ & 6 & $1.96 \mathrm{E}-09$ & $4.86 \mathrm{E}-06$ & - \\
\hline \multirow[t]{2}{*}{ HSP90AA1 } & \multirow[t]{2}{*}{ chr14:102554826-102554978 } & $\mathrm{NO}_{2}$ & $\mathrm{t} 3$ & 4 & $8.60 \mathrm{E}-08$ & $2.41 \mathrm{E}-04$ & - \\
\hline & & $\mathrm{NO}_{2}$ & $\mathrm{~m}$ & 4 & $6.66 \mathrm{E}-09$ & $1.87 \mathrm{E}-05$ & - \\
\hline IL32 & chr16:3114986-3115134 & $\mathrm{NO}_{2}$ & $\mathrm{~m}$ & 3 & $4.45 \mathrm{E}-09$ & $1.28 \mathrm{E}-05$ & + \\
\hline LIME1 & chr20:62369445-62369606 & $\mathrm{PM}_{10}$ & $\mathrm{~d} 2$ & 4 & $1.38 \mathrm{E}-08$ & $3.64 \mathrm{E}-05$ & - \\
\hline LMF1 & chr16:967929-968025 & $\mathrm{NO}_{2}$ & $\mathrm{t} 3$ & 3 & $5.54 \mathrm{E}-08$ & $2.46 \mathrm{E}-04$ & - \\
\hline \multirow[t]{2}{*}{ LOC254559 } & \multirow[t]{2}{*}{ chr15:89921083-89921259 } & $\mathrm{NO}_{2}$ & $\mathrm{t} 3$ & 6 & $3.97 \mathrm{E}-08$ & $1.64 \mathrm{E}-04$ & - \\
\hline & & $\mathrm{NO}_{2}$ & $\mathrm{~m}$ & 7 & 2.02E-09 & $4.90 \mathrm{E}-06$ & - \\
\hline \multirow[t]{3}{*}{ LZTFL1 } & \multirow[t]{3}{*}{ chr3:45883529-45883735 } & $\mathrm{NO}_{2}$ & $\mathrm{p}$ & 7 & $1.16 \mathrm{E}-07$ & $2.39 \mathrm{E}-04$ & + \\
\hline & & $\mathrm{NO}_{2}$ & $\mathrm{t} 3$ & 8 & $2.75 \mathrm{E}-10$ & 4.37E-07 & + \\
\hline & & $\mathrm{NO}_{2}$ & $\mathrm{~m}$ & 10 & $1.51 \mathrm{E}-11$ & $1.94 \mathrm{E}-08$ & + \\
\hline NOTCH3 & chr19:15281200-15281518 & $\mathrm{PM}_{10}$ & $\mathrm{~d} 1$ & 4 & $5.03 \mathrm{E}-12$ & $6.73 \mathrm{E}-09$ & - \\
\hline \multirow[t]{3}{*}{$\mathrm{P} 2 \mathrm{RX} 4$} & \multirow[t]{3}{*}{ chr12:121647128-121647218 } & $\mathrm{NO}_{2}$ & $\mathrm{p}$ & 5 & $7.16 \mathrm{E}-08$ & 3.39E-04 & + \\
\hline & & $\mathrm{NO}_{2}$ & $\mathrm{t} 3$ & 5 & 8.03E-08 & $3.80 \mathrm{E}-04$ & + \\
\hline & & $\mathrm{NO}_{2}$ & $\mathrm{~m}$ & 5 & $5.51 \mathrm{E}-11$ & $2.61 \mathrm{E}-07$ & + \\
\hline PRRT1 & chr6:32116538-32116781 & $\mathrm{PM}_{10}$ & $\mathrm{~d} 2$ & 5 & 3.64E-09 & $6.38 \mathrm{E}-06$ & - \\
\hline SOX2OT;SOX2 & chr3:181428462-181428580 & $\mathrm{PM}_{10}$ & $\mathrm{~m}$ & 5 & $6.05 \mathrm{E}-08$ & $2.18 \mathrm{E}-04$ & + \\
\hline TRIO & chr5:14359544-14359615 & $\mathrm{PM}_{10}$ & $\mathrm{~m}$ & 3 & $1.44 \mathrm{E}-08$ & $8.66 \mathrm{E}-05$ & + \\
\hline \multirow[t]{3}{*}{ ZNF563 } & chr19:12444484-12444742 & $\mathrm{PM}_{10}$ & $\mathrm{~m}$ & 6 & $3.21 \mathrm{E}-11$ & $5.29 \mathrm{E}-08$ & + \\
\hline & chr3:194650099-194650198 & $\mathrm{NO}_{2}$ & $\mathrm{t} 3$ & 2 & $6.78 \mathrm{E}-08$ & $2.92 \mathrm{E}-04$ & + \\
\hline & chr6:28583971-28584173 & $\mathrm{NO}_{2}$ & $\mathrm{~m}$ & 15 & $6.42 \mathrm{E}-09$ & $1.35 \mathrm{E}-05$ & - \\
\hline
\end{tabular}


trimester 2. t3: trimester 3. d1: day 1 before birth. d2: day 2 before birth. d3: day 3 before birth; ${ }^{1}$

\subsection{Synthesis of the results}

440 Our top finding was that one $\mathrm{CpG}(\operatorname{cg} 17580614)$ located in the body of $A D O R A 2 B$, one of the 441 placenta-predominantly expressed genes, showed a significantly lower methylation in placenta after $442 \mathrm{NO}_{2}$ exposure during pregnancy. This result came out of the concept-driven analysis performed on $44318,972 \mathrm{CpGs}$ and was confirmed in the agnostic approach that used a more stringent FDR 444 correction of the p-values on $425,878 \mathrm{CpGs}$ and in the regional analysis. Furthermore, this $\mathrm{CpG}$ as 445 well as another $A D O R A 2 B \mathrm{CpG}(\operatorname{cg} 07563400)$ were in the top 20 of $\mathrm{CpGs}$ associated with $\mathrm{NO}_{2}$ 446 exposure during the $1^{\text {st }}$ and $2^{\text {nd }}$ trimesters and during the whole pregnancy (FDR p-values $\leq 0.1$, 447 Supplemental material, Table S6). Figure 4 shows the regression coefficient for each of the 448 ADORA2B CpGs against its uncorrected p-value regarding the association with $\mathrm{NO}_{2}$ exposure 449 during the $2^{\text {nd }}$ trimester and the whole pregnancy. Among the 19 CpGs of this gene, 16 were 450 negatively associated with $\mathrm{NO}_{2}$ exposure during the 2nd trimester and the whole pregnancy, and 11 451 (10, respectively) were in the top 1000 of the CpGs associated with placenta-predominantly expressed genes (Figure 4).

Figure 4: Visualisation of regional associations between $\mathrm{NO}_{2}$ exposure during pregnancy and $454 A D O R A 2 B$ methylation indicating the direction of the effect (coefficient) and confidence interval 455 for each $\mathrm{CpG}$.

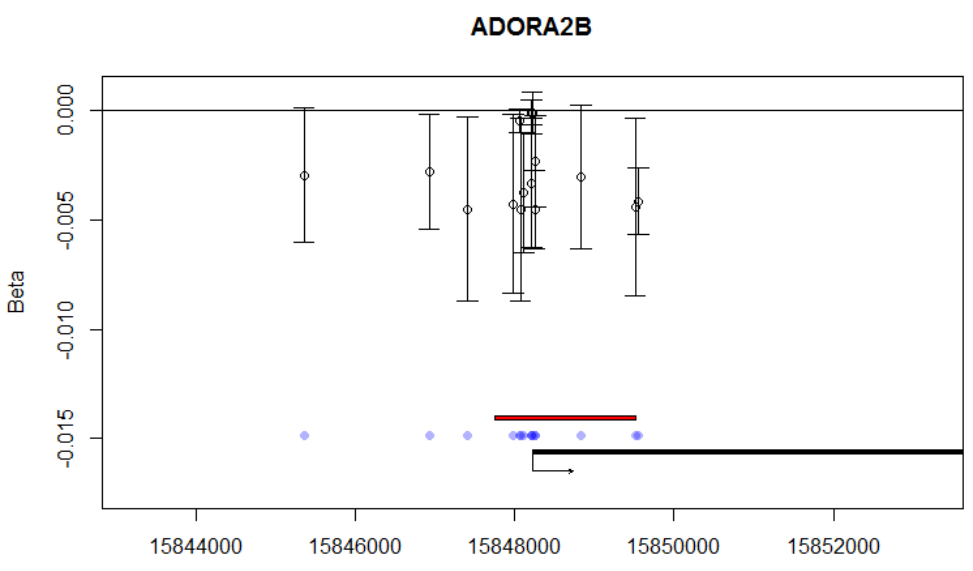




\section{Discussion}

To the best of our knowledge, the present study shows the results of the first genome-wide analysis of differentially methylated probes and regions in placenta in relation to in utero exposure to $\mathrm{PM}_{10}$, $\mathrm{NO}_{2}$, temperature and humidity. Associating a concept-driven analysis with an agnostic EWAS, we showed lower methylation levels in two CpGs located in the body of $A D O R A 2 B$ associated with increased exposure to $\mathrm{NO}_{2}$ during pregnancy, especially in trimesters 1 and 2. The agnostic EWAS further revealed new significant associations of prenatal exposure to $\mathrm{PM}_{10}, \mathrm{NO}_{2}$, humidity and temperature during various time-windows and methylation of 4 CpGs (mapped to 2 genes (PSD3, ZNF709) and 2 non genic regions) and 39 regions (Table 3, Table S9), which are candidates for replication in future studies. Among these, several DMR were located in genes pointing towards hypertensive and metabolic disorders.

$A D O R A 2 B$, encoding the Adenosine $\mathrm{A} 2 \mathrm{~B}$ receptor, was shown to play a role in placental development and possibly in the pathophysiology of hypoxia and preeclampsia (PE) in pregnant women (Acurio et al., 2014; Darashchonak et al., 2014; Jia et al., 2012), a pathology which has also been associated with air pollution exposure during pregnancy (M. Pedersen et al., 2014). In both mice and humans, it has been demonstrated that activation of ADORA2B signalling contributes to the pathogenesis of PE (Huang et al., 2017), to small foetuses, small placentas and foetal growth restriction (Iriyama et al., 2015). The molecular basis of the functional link and relationship between $A D O R A 2 B$ gene and placenta DNA methylation, and the involvement of the ADORA2B protein in PE and birth outcomes are questions to be addressed in future investigations. Additional work will also be required to assess the relevance of $A D O R A 2 B$ as a candidate marker and/or target for the diagnosis, prevention and treatment of PE.

Of interest, four DMR were located in CD81, DAXX, NOTCH3 and P2RX4 genes, which have all been implicated in PE phenotypes. $P 2 R X 4$, a purinergic receptor highly expressed in normal placentas, was shown to be overexpressed in both term and preterm preeclamptic placentas (Roberts 
et al., 2007) and hypomethylated in preeclamptic placentas (Chu et al., 2014). In our study, $\mathrm{NO}_{2}$

483 exposure in pregnancy, $3^{\text {rd }}$ trimester and last month of pregnancy was positively associated with $P 2 R X 4$ methylation. In accordance with our result, a $\mathrm{CpG}$ of $P 2 R X 4$ was found hypermethylated in blood from adults exposed to $\mathrm{PM}_{2.5}$ in the previous month (Panni et al., 2016). In addition, our results indicated a positive association of $\mathrm{PM}_{10}$ exposure the day before birth with methylation in a DMR located in CD81 and a negative association with DMRs in DAXX and NOTCH3. CD81, a gene encoding a member of the transmembrane 4 superfamily, was shown to be mainly expressed in normal first trimester placentas and gradually downregulated with gestational age (Shen et al., 2017). In early-onset ( $\leq 34$ weeks) severe preeclamptic placentas, $C D 81$ was up-regulated in syncytiotrophoblasts and extravillous cytotrophoblasts, which play a major role in maternal-fetal exchanges (Malassiné and Cronier, 2002) and placentation (Pijnenborg et al., 2006). The overexpression of $C D 81$ was also demonstrated in a PE-like phenotype in rats (Shen et al., 2017). A recent study demonstrated that $D A X X$ methylation was involved in trophoblast differentiation, PE, and response to hypoxia, suggesting an important role of $D A X X$ in placentation (Novakovic et al., 2017). Similarly, NOTCH3 placental expression has been shown down regulated in PE (Fragkiadaki et al., 2015) and up regulated in early onset PE (Zhao et al., 2014). Notch signaling has been suggested to play a key role in cytotrophoblasts motility and differentiation (Haider et al., 2014). In contrast to our finding, NOTCH3 methylation in blood form adults has been positively associated with $\mathrm{PM}_{2.5}$ exposure the previous month (Panni et al., 2016). Further studies are required in order to determine the functional relationship between these genes and their placental methylation. 503 are increasingly suspected as a potential mechanism to explain health effects of air pollutants (Shah et al., 2013).

Among air pollutants associated DMR in our study, four were located in LMF1, GNAS, GNASAS, and $I L-32$ genes. These genes have been previously involved in metabolic syndrome and related phenotypes (Hong et al., 2017). Single nucleotide polymorphisms of LMF1 is involved in severe 
hypertriglyceridemia (Péterfy, 2012). LMF1 blood methylation in adults has been positively associated with $\mathrm{PM}_{2.5}$ exposure in the previous month (Panni et al., 2016), while our results indicated a negative association of $\mathrm{NO}_{2}$ exposure in the $3^{\text {rd }}$ trimester with placental methylation of this gene. GNAS is an imprinted gene with a complex imprinted pattern; decreased placental expression has been associated with intra uterine growth retardation (Dunk et al., 2012; McMinn et al., 2006) and cord blood hypermetylation has been associated with gestational diabetes (D. Chen 514 et al., 2014). GNASAS, the GNAS antisense RNA 1, placental expression was related to newborns neurobehavioral profile (Green et al., 2016), while its methylation in adult blood has been linked to prenatal exposure to famine (Tobi et al., 2009). In rabbits, pregnancy exposure to diesel engine exhaust has been associated with changes in triglyceride and cholesterol levels in the offspring exposed in utero (Valentino et al., 2015) but further investigations are required to identify if this association could be to some extent mediated by epigenetic changes. Taken together our findings point to PE- and metabolic syndrome-associated genes, which is in line with the increasing evidence on the relationship between air pollution and the metabolic syndrome (B.-Y. Yang et al., 2018) and with the hypothesis that such effects might start early in life (Park, 2017).

Significant variations of the methylation levels of other CpGs and DMR, identified either from the concept-driven analysis or from the agnostic EWAS approach, have occasionally been found associated with $\mathrm{NO}_{2}, \mathrm{PM}_{10}$, temperature or humidity exposure at specific time windows of pregnancy. However, the biological significance of the differential methylation observed for these genes is unclear (Supplemental material, Table S10). These genes have not been associated with $528 \mathrm{NO}_{2}$ or proximity to traffic in the two recent EWAS conducted in newborns (Gruzieva et al., 2017; 529 Kingsley et al., 2016). Noteworthy, some of these results were in agreement with air pollution association studies conducted on blood DNA methylation. This was the case for the positive 531 association of methylation in LZTFL1-DMR with average $\mathrm{NO}_{2}$ exposure during pregnancy, $3^{\text {rd }}$ 532 trimester and last month of pregnancy which was consistent with the relationship between LZTFL1 533 blood methylation and chronic $\mathrm{PM}_{2.5}$ exposure observed in an elderly population (Nwanaji- 
534 Enwerem et al., 2016). The significant (FDR corrected) associations of $\mathrm{PM}_{2.5}$ exposure in the past 535 month and decreased blood methylation in ANKRD45 and LOC254559 and increased blood methylation in TRIO found by Panni (Panni et al., 2016) was in agreement with our findings in the placenta. However, the negative relationship they found between $\mathrm{PM}_{2.5}$ exposure and ZNF563 methylation disagree with our results. The small overlap between our results and those of previous published EWAS can be explained by the fact that these studies relied on different tissues. Gruzieva et al. investigated cord blood (Gruzieva et al., 2017) and Kingsley et al. examined placenta samples from the maternal side (Kingsley et al., 2016). DNA methylation is tissue-specific (Ollikainen et al., 2010) and it is likely that different tissue will respond differently to similar environmental stimuli. The fact that DNA methylation is a dynamic mark also explains this absence of overlap between the present results obtained in our population of newborns and other data obtained for different populations and exposure levels.

Breton et al. (Breton et al., 2016) found that prenatal exposure to $\mathrm{PM}_{10}$ in the first trimester was associated with lower LINE-1 methylation in 459 newborn bloodspots. A similar result was found in 471 placenta samples where LINE-1 was associated with distance to traffic (Kingsley et al., 2016) and in 240 placenta samples where global methylation was linked to first trimester exposure to $\mathrm{PM}_{2.5}$ (Janssen et al., 2013). These studies did not investigate shorter time-windows of exposure. In our study, we also observed a negative relationship between $\mathrm{PM}_{10}$ exposure during the first trimester and LINE-1 and Alu CpG methylation, but our results did not reach statistical significance. In the short-term, $\mathrm{PM}_{10}$ exposure the day before birth was significantly and positively associated with Alu repetitive elements methylation.

As for meteorological conditions, we observed a trend for temperature in the first trimester of pregnancy being associated with the methylation distribution profiles ( $\mathrm{p}$-value for density function $557=0.03, \mathrm{p}$-value for cumulative distribution function $=0.11)$. We are aware of only one previous 558 study investigating the effects of meteorological conditions on DNA methylation in blood cells of elderly men (Bind et al., 2014). The authors reported associations of ambient temperature with 
DNA methylation in genes related to coagulation, inflammation, cortisol, and metabolic pathway

561 and associations of relative humidity with LINE-1 hypomethylation and Alu hypermethylation. In our study, we found two loci, one in ZNF709 and one in a non genic region whose methylation was associated with humidity exposure during the second trimester and the month preceding birth, respectively. We also identified 13 DMRs mapping to 8 genes associated with meteorological exposures. These genes do not seem involved in the inflammation or metabolic pathways previously highlighted with blood methylation, and their association with prenatal meteorological conditions had not been examined so far.

A novel feature of our study is the focus on genes with tissue specific patterns of expression, in which we identified first a category of genes that are mostly active in the placenta and silent in other tissues ("active genes") and second a category of genes with a methylation-dependent repressed state ("silent genes") in the placenta. The definition of silent and active chromatin points to regions with different dynamics and hence different capacity to respond to signals and to be reprogrammed. In order to identify these regions, we used available transcriptomic data (for selecting genes with specific patterns of expression in placenta) and the present methylome data (list of silent genes with high methylation levels). This original approach not only allowed us to identify potential target CpGs through the activity of their regulatory regions, but also to limit the number of $\mathrm{CpG}$ sites to the most relevant ones to be tested in relation to environmental exposures, without limiting the analysis to particular pathways previously identified in the literature. In the context of a constantly expanding number of CpGs interrogated by microarrays and sequencing 580 techniques, which usually exceeds the sample size of the study, replication is often used to validate 581 the findings and limit the risk of false positives. Our strategy was rather to restrict our analysis to 582 the most biologically relevant genes and chromatin regions, which we defined as those prone to be 583 affected by alterations in methylation. Noteworthy, the results of the EWAS, which used a more 584 stringent correction of the p-value, and the DMR analyses strongly supports our finding from the 
concept-driven analysis that $A D O R A 2 B$ placental methylation could be sensitive to prenatal air pollution exposure.

We acknowledge several strengths and limitations to this study. First, our results demonstrate that placental DNA methylation is associated with air pollutants exposure, but we cannot draw conclusions on how gene expression relates to these methylation differences. Second, our study focused on $\mathrm{PM}_{10}$ and $\mathrm{NO}_{2}$ air pollutants exposure, for which high temporally and spatially resolved exposures were available. Air pollution is a complex mixture of compounds which are correlated with the assessed pollutants. $\mathrm{PM}_{2.5}$ are of great concern because they can penetrate deep into the lungs and enter the blood circulation. While our results identified mainly $\mathrm{NO}_{2}$ exposure as associated with placental DNA methylation, we rather interpret this association as an indication of traffic-pollutants association with DNA methylation. Another limitation is the use of residential address to estimate air pollution exposure, which is prone to misclassification due to the lack of consideration of time activity patterns and of indoor exposures. However, we used a high spatially and temporally resolved ambient dispersion model. Third, although we attempted to account for many potential confounders including technical factors and cell heterogeneity, we cannot rule out confounding from unaccounted factors such as physical activity, diet, or genetics. Moreover, since our cohort consists of highly educated mainly Caucasian women, our findings may not be generalizable to other populations. An important strength is that the sample size is one of the largest for a study on placental DNA methylation and more generally for an environmental epigenetic study. Samples were collected from the foetal side of the placenta, which is relatively easy to collect, noninvasive and may allow a good reproducibility of results since the placenta lifetime is limited to the pregnancy. In perinatal studies, the placenta represents a relevant tissue considered as an accurate 'record' of children's in-utero exposures (Maccani and Marsit, 2009) and as a health biomarker due characterized mother-child cohort, which allowed the consideration of a large range of potential confounders, including data collected early in pregnancy. 


\section{Conclusions}

Among the placenta methylated silent genes, we identified four CpGs, mapped to four genes, whose methylation levels in the foetal placenta were significantly associated with maternal exposures to $\mathrm{NO}_{2}$ and $\mathrm{PM}_{10}$. Among placenta active genes, we found five CpGs, mapped to five genes, whose methylation levels in the foetal placenta were significantly associated with maternal exposures to

$618 \mathrm{NO}_{2}$ and $\mathrm{PM}_{10}$. One of these active genes, $A D O R A 2 B$, had $2 \mathrm{CpGs}$ whose methylation levels were 619 also significantly associated with $\mathrm{NO}_{2}$ exposure during the second trimester of pregnancy in the 620 EWAS approach after FDR correction of the p-value. The DMRs analyses showed ADORA2B methylation as associated with $\mathrm{NO}_{2}$ exposure in pregnancy and at each trimester of pregnancy. $A D O R A 2 B$ has been implicated in placental development, hypoxia and preeclampsia, a pathology which has been previously associated with air pollution exposure during pregnancy. This latter observation, together with our results, supports the hypothesis that placental DNA methylation is involved in the exposure-disease relationships during pregnancy. Whether the observed associations potentially bear long-term consequences for the health of the child and adult individual, or even possibly for future generations, remains to be investigated.

\section{Acknowledgments}

630 We thank the midwife research assistants (L. Douhaud. S. Bedel. B. Lortholary. S. Gabriel. M. 631 Rogeon. and M. Malinbaum) for data collection and P. Lavoine for checking, coding, and entering 632 data. The EDEN mother-child cohort study group includes: I Annesi-Maesano, JY Bernard, J 633 Botton, M-A Charles, P Dargent-Molina, B de Lauzon-Guillain, P Ducimetière, M de Agostini, B 634 Foliguet, A Forhan, X Fritel, A Germa, V Goua, R Hankard, B Heude, M Kaminski, B Larroque, N 635 Lelong, J Lepeule, G Magnin, L Marchand, C Nabet, F Pierre, R Slama, MJ Saurel-Cubizolles, M 
Schweitzer, O Thiebaugeorges. We thank Emie Seyve for her help in the preparation of the revised

manuscript and the reviewers for their insightful comments that improved the manuscript.

\section{References}

Acurio, J., Troncoso, F., Bertoglia, P., Salomon, C., Aguayo, C., Sobrevia, L., Escudero, C., 2014. Potential role of $\mathrm{A} 2 \mathrm{~B}$ adenosine receptors on proliferation/migration of fetal endothelium derived from preeclamptic pregnancies. Biomed Res Int 2014, 274507. doi:10.1155/2014/274507

Beltran, A., Wu, J., Laurent, O., 2014. Associations of Meteorology with Adverse Pregnancy Outcomes: A Systematic Review of Preeclampsia, Preterm Birth and Birth Weight. IJERPH 11, 91-172. doi:10.3390/ijerph110100091

Benjamini, Y., Hochberg, Y., 1995. Controlling the false discovery rate: a practical and powerful approach to multiple testing. Journal of the royal statistical society Series B ( . . 57, 289-300.

Bind, M.-A., Zanobetti, A., Gasparrini, A., Peters, A., Coull, B., Baccarelli, A., Tarantini, L., Koutrakis, P., Vokonas, P., Schwartz, J., 2014. Effects of temperature and relative humidity on DNA methylation. Epidemiology 25, 561-569. doi:10.1097/EDE.0000000000000120

Breton, C.V., Yao, J., Millstein, J., Gao, L., Siegmund, K.D., Mack, W., Whitfield-Maxwell, L., Lurmann, F., Hodis, H., Avol, E., Gilliland, F.D., 2016. Prenatal Air Pollution Exposures, DNA Methyl Transferase Genotypes, and Associations with Newborn LINE1 and Alu Methylation and Childhood Blood Pressure and Carotid Intima-Media Thickness in the Children's Health Study. Environ. Health Perspect. 124, 1905-1912. doi:10.1289/EHP181

Cai, J., Zhao, Y., Liu, P., Xia, B., Zhu, Q., Wang, X., Song, Q., Kan, H., Zhang, Y., 2017. Exposure to particulate air pollution during early pregnancy is associated with placental DNA methylation. Sci. Total Environ. 607-608, 1103-1108. doi:10.1016/j.scitotenv.2017.07.029

Chen, D., Zhang, A., Fang, M., Fang, R., Ge, J., Jiang, Y., Zhang, H., Han, C., Ye, X., Huang, H., Liu, Y., Dong, M., 2014. Increased methylation at differentially methylated region of GNAS in infants born to gestational diabetes. BMC Med. Genet. 15, 108. doi:10.1186/s12881-014-01083

Chen, Y.-A., Lemire, M., Choufani, S., Butcher, D.T., Grafodatskaya, D., Zanke, B.W., Gallinger, S., Hudson, T.J., Weksberg, R., 2013. Discovery of cross-reactive probes and polymorphic CpGs in the Illumina Infinium HumanMethylation450 microarray. Epigenetics 8, 203-209. doi:10.4161/epi.23470

Chiu, Y.-H.M., Hsu, H.-H.L., Coull, B.A., Bellinger, D.C., Kloog, I., Schwartz, J., Wright, R.O., Wright, R.J., 2016. Prenatal particulate air pollution and neurodevelopment in urban children: Examining sensitive windows and sex-specific associations. Environ Int 87, 56-65. doi:10.1016/j.envint.2015.11.010

Chu, T., Bunce, K., Shaw, P., Shridhar, V., Althouse, A., Hubel, C., Peters, D., 2014. Comprehensive analysis of preeclampsia-associated DNA methylation in the placenta. PLoS ONE 9, e107318. doi:10.1371/journal.pone.0107318

Clifford, A., Lang, L., Chen, R., Anstey, K.J., Seaton, A., 2016. Exposure to air pollution and cognitive functioning across the life course - A systematic literature review. Environ. Res. 147, 383-398. doi:10.1016/j.envres.2016.01.018

Darashchonak, N., Sarisin, A., Kleppa, M.-J., Powers, R.W., Versen-Höynck, von, F., 2014. Activation of adenosine A2B receptor impairs properties of trophoblast cells and involves mitogen-activated protein (MAP) kinase signaling. Placenta 35, 763-771. doi:10.1016/j.placenta.2014.06.369

Devlin, B., Roeder, K., Wasserman, L., 2001. Genomic control, a new approach to genetic-based association studies. Theor Popul Biol 60, 155-166. doi:10.1006/tpbi.2001.1542

Du, P., Kibbe, W.A., Lin, S.M., 2008. lumi: a pipeline for processing Illumina microarray. Bioinformatics 24, 1547-1548. doi:10.1093/bioinformatics/btn224 
Dunk, C.E., Roggensack, A.M., Cox, B., Perkins, J.E., Åsenius, F., Keating, S., Weksberg, R., Kingdom, J.C.P., Adamson, S.L., 2012. A distinct microvascular endothelial gene expression profile in severe IUGR placentas. Placenta 33, 285-293. doi:10.1016/j.placenta.2011.12.020

Fragkiadaki, P., Soulitzis, N., Sifakis, S., Koutroulakis, D., Gourvas, V., Vrachnis, N., Spandidos, D.A., 2015. Downregulation of notch signaling pathway in late preterm and term placentas from pregnancies complicated by preeclampsia. PLoS ONE 10, e0126163. doi:10.1371/journal.pone.0126163

Giorgis-Allemand, L., Pedersen, M., Bernard, C., Aguilera, I., Beelen, R.M.J., Chatzi, L., Cirach, M., Danileviciute, A., Dedele, A., van Eijsden, M., Estarlich, M., Fernández-Somoano, A., Fernández, M.F., Forastiere, F., Gehring, U., Grazuleviciene, R., Gruzieva, O., Heude, B., Hoek, G., de Hoogh, K., van den Hooven, E.H., Håberg, S.E., Iñiguez, C., Jaddoe, V.W.V., Korek, M., Lertxundi, A., Lepeule, J., Nafstad, P., Nystad, W., Patelarou, E., Porta, D., Postma, D., Raaschou-Nielsen, O., Rudnai, P., Siroux, V., Sunyer, J., Stephanou, E., Sørensen, M., Eriksen, K.T., Tuffnell, D., Varró, M.J., Vrijkotte, T.G.M., Wijga, A., Wright, J., Nieuwenhuijsen, M.J., Pershagen, G., Brunekreef, B., Kogevinas, M., Slama, R., 2017. The Influence of Meteorological Factors and Atmospheric Pollutants on the Risk of Preterm Birth. Am J Epidemiol. doi:10.1093/aje/kww141

Green, B.B., Karagas, M.R., Punshon, T., Jackson, B.P., Robbins, D.J., Houseman, E.A., Marsit, C.J., 2016. Epigenome-Wide Assessment of DNA Methylation in the Placenta and Arsenic Exposure in the New Hampshire Birth Cohort Study (USA). Environ. Health Perspect. 124, 1253-1260. doi:10.1289/ehp.1510437

Gruzieva, O., Xu, C.-J., Breton, C.V., Annesi-Maesano, I., Antó, J.M., Auffray, C., Ballereau, S., Bellander, T., Bousquet, J., Bustamante, M., Charles, M.-A., de Kluizenaar, Y., Dekker, den, H.T., Duijts, L., Felix, J.F., Gehring, U., Guxens, M., Jaddoe, V.V.W., Jankipersadsing, S.A., Merid, S.K., Kere, J., Kumar, A., Lemonnier, N., Lepeule, J., Nystad, W., Page, C.M., Panasevich, S., Postma, D., Slama, R., Sunyer, J., Söderhäll, C., Yao, J., London, S.J., Pershagen, G., Koppelman, G.H., Melén, E., 2017. Epigenome-Wide Meta-Analysis of Methylation in Children Related to Prenatal NO2 Air Pollution Exposure. Environ. Health Perspect. 125, 104-110. doi:10.1289/EHP36

Haider, S., Meinhardt, G., Velicky, P., Otti, G.R., Whitley, G., Fiala, C., Pollheimer, J., Knöfler, M., 2014. Notch signaling plays a critical role in motility and differentiation of human firsttrimester cytotrophoblasts. Endocrinology 155, 263-274. doi:10.1210/en.2013-1455

Heude, B., Forhan, A., Slama, R., Douhaud, L., Bedel, S., Saurel-Cubizolles, M.-J., Hankard, R., Thiebaugeorges, O., De Agostini, M., Annesi-Maesano, I., Kaminski, M., Charles, M.-A., EDEN Mother-Child Cohort Study Group, 2015. Cohort Profile: The EDEN mother-child cohort on the prenatal and early postnatal determinants of child health and development. Int $\mathbf{J}$ Epidemiol. doi:10.1093/ije/dyv151

Hong, J.T., Son, D.J., Lee, C.K., Yoon, D.-Y., Lee, D.H., Park, M.H., 2017. Interleukin 32, inflammation and cancer. Pharmacol. Ther. 174, 127-137. doi:10.1016/j.pharmthera.2017.02.025

Houseman, E.A., Kile, M.L., Christiani, D.C., Ince, T.A., Kelsey, K.T., Marsit, C.J., 2016. Reference-free deconvolution of DNA methylation data and mediation by cell composition effects. BMC Bioinformatics 17, 259. doi:10.1186/s12859-016-1140-4

Huang, A., Wu, H., Iriyama, T., Zhang, Y., Sun, K., Song, A., Liu, H., Peng, Z., Tang, L., Lee, M., Huang, Y., Ni, X., Kellems, R.E., Xia, Y., 2017. Elevated Adenosine Induces Placental DNA Hypomethylation Independent of A2B Receptor Signaling in Preeclampsia. Hypertension 70, 209-218. doi:10.1161/HYPERTENSIONAHA.117.09536

Iriyama, T., Sun, K., Parchim, N.F., Li, J., Zhao, C., Song, A., Hart, L.A., Blackwell, S.C., Sibai, B.M., Chan, L.-N.L., Chan, T.-S., Hicks, M.J., Blackburn, M.R., Kellems, R.E., Xia, Y., 2015. Elevated placental adenosine signaling contributes to the pathogenesis of preeclampsia. Circulation 131, 730-741. doi:10.1161/CIRCULATIONAHA.114.013740

Janssen, B.G., Godderis, L., Pieters, N., Poels, K., Kiciński, M., Cuypers, A., Fierens, F., Penders, J., Plusquin, M., Gyselaers, W., Nawrot, T.S., 2013. Placental DNA hypomethylation in 
association with particulate air pollution in early life. Part Fibre Toxicol 10, 22. doi:10.1186/1743-8977-10-22

Jedrychowski, W.A., Perera, F.P., Maugeri, U., Mroz, E., Klimaszewska-Rembiasz, M., Flak, E., Edwards, S., Spengler, J.D., 2010. Effect of prenatal exposure to fine particulate matter on ventilatory lung function of preschool children of non-smoking mothers. Paediatr Perinat Epidemiol 24, 492-501. doi:10.1111/j.1365-3016.2010.01136.x

Jia, R.-Z., Zhang, X., Hu, P., Liu, X.-M., Hua, X.-D., Wang, X., Ding, H.-J., 2012. Screening for differential methylation status in human placenta in preeclampsia using a $\mathrm{CpG}$ island plus promoter microarray. Int. J. Mol. Med. 30, 133-141. doi:10.3892/ijmm.2012.983

Kingsley, S.L., Eliot, M.N., Whitsel, E.A., Huang, Y.-T., Kelsey, K.T., Marsit, C.J., Wellenius, G.A., 2016. Maternal residential proximity to major roadways, birth weight, and placental DNA methylation. Environ Int 92-93, 43-49. doi:10.1016/j.envint.2016.03.020

Kloog, I., Melly, S.J., Coull, B.A., Nordio, F., Schwartz, J.D., 2015. Using Satellite-Based Spatiotemporal Resolved Air Temperature Exposure to Study the Association between Ambient Air Temperature and Birth Outcomes in Massachusetts. Environ. Health Perspect. doi:10.1289/ehp.1308075

Maccani, M.A., Marsit, C.J., 2009. Epigenetics in the placenta. Am. J. Reprod. Immunol. 62, 7889. doi:10.1111/j.1600-0897.2009.00716.x

Madrigano, J., Baccarelli, A., Mittleman, M.A., Wright, R.O., Sparrow, D., Vokonas, P.S., Tarantini, L., Schwartz, J., 2011. Prolonged exposure to particulate pollution, genes associated with glutathione pathways, and DNA methylation in a cohort of older men. Environ. Health Perspect. 119, 977-982. doi:10.1289/ehp.1002773

Malassiné, A., Cronier, L., 2002. Hormones and human trophoblast differentiation: a review. Endocrine 19, 3-11. doi:10.1385/ENDO:19:1:3

McMinn, J., Wei, M., Schupf, N., Cusmai, J., Johnson, E.B., Smith, A.C., Weksberg, R., Thaker, H.M., Tycko, B., 2006. Unbalanced placental expression of imprinted genes in human intrauterine growth restriction. Placenta 27, 540-549. doi:10.1016/j.placenta.2005.07.004

Murphy, V.E., Smith, R., Giles, W.B., Clifton, V.L., 2006. Endocrine regulation of human fetal growth: the role of the mother, placenta, and fetus. Endocr. Rev. 27, 141-169. doi:10.1210/er.2005-0011

Nelissen, E.C.M., van Montfoort, A.P.A., Dumoulin, J.C.M., Evers, J.L.H., 2011. Epigenetics and the placenta. Hum. Reprod. Update 17, 397-417. doi:10.1093/humupd/dmq052

Novakovic, B., Evain-Brion, D., Murthi, P., Fournier, T., Saffery, R., 2017. VariableDAXXgene methylation is a common feature of placental trophoblast differentiation, preeclampsia, and response to hypoxia. The FASEB Journal 31, 2380-2392. doi:10.1096/fj.201601189RR

Nwanaji-Enwerem, J.C., Colicino, E., Trevisi, L., Kloog, I., Just, A.C., Shen, J., Brennan, K., Dereix, A., Hou, L., Vokonas, P., Schwartz, J., Baccarelli, A.A., 2016. Long-term ambient particle exposures and blood DNA methylation age: findings from the VA normative aging study. Environ Epigenet 2. doi:10.1093/eep/dvw006

Ollikainen, M., Smith, K.R., Joo, E.J.-H., Ng, H.K., Andronikos, R., Novakovic, B., Abdul Aziz, N.K., Carlin, J.B., Morley, R., Saffery, R., Craig, J.M., 2010. DNA methylation analysis of multiple tissues from newborn twins reveals both genetic and intrauterine components to variation in the human neonatal epigenome. Human Molecular Genetics 19, 4176-4188. doi: $10.1093 / \mathrm{hmg} / \mathrm{ddq} 336$

Ortiz, E.A.G., 2017. Air quality in Europe - 2016 report 1-88.

Panni, T., Mehta, A.J., Schwartz, J.D., Baccarelli, A.A., Just, A.C., Wolf, K., Wahl, S., Cyrys, J., Kunze, S., Strauch, K., Waldenberger, M., Peters, A., 2016. Genome-Wide Analysis of DNA Methylation and Fine Particulate Matter Air Pollution in Three Study Populations: KORA F3, KORA F4, and the Normative Aging Study. Environ. Health Perspect. 124, 983-990. doi:10.1289/ehp.1509966

Park, S.K., 2017. Ambient Air Pollution and Type 2 Diabetes: Do the Metabolic Effects of Air Pollution Start Early in Life? Diabetes 66, 1755-1757. doi:10.2337/dbi17-0012

Pedersen, B.S., Schwartz, D.A., Yang, I.V., Kechris, K.J., 2012. Comb-p: software for combining, 
analyzing, grouping and correcting spatially correlated P-values. Bioinformatics 28, 29862988. doi:10.1093/bioinformatics/bts545

Pedersen, M., Stayner, L., Slama, R., Sørensen, M., Figueras, F., Nieuwenhuijsen, M.J., RaaschouNielsen, O., Dadvand, P., 2014. Ambient air pollution and pregnancy-induced hypertensive disorders: a systematic review and meta-analysis. Hypertension 64, 494-500. doi:10.1161/HYPERTENSIONAHA.114.03545

Péterfy, M., 2012. Lipase maturation factor 1: a lipase chaperone involved in lipid metabolism. Biochim. Biophys. Acta 1821, 790-794. doi:10.1016/j.bbalip.2011.10.006

Pijnenborg, R., Vercruysse, L., Hanssens, M., 2006. The uterine spiral arteries in human pregnancy: facts and controversies. Placenta 27, 939-958. doi:10.1016/j.placenta.2005.12.006

Price, M.E., Cotton, A.M., Lam, L.L., Farré, P., Emberly, E., Brown, C.J., Robinson, W.P., Kobor, M.S., 2013. Additional annotation enhances potential for biologically-relevant analysis of the Illumina Infinium HumanMethylation450 BeadChip array. Epigenetics Chromatin 6, 4. doi:10.1186/1756-8935-6-4

Roberts, V.H.J., Webster, R.P., Brockman, D.E., Pitzer, B.A., Myatt, L., 2007. Post-Translational Modifications of the $\mathrm{P} 2 \mathrm{X}(4)$ purinergic receptor subtype in the human placenta are altered in preeclampsia. Placenta 28, 270-277. doi:10.1016/j.placenta.2006.04.008

Rousseaux, S., Debernardi, A., Jacquiau, B., Vitte, A.-L., Vesin, A., Nagy-Mignotte, H., MoroSibilot, D., Brichon, P.-Y., Lantuejoul, S., Hainaut, P., Laffaire, J., de Reyniès, A., Beer, D.G., Timsit, J.-F., Brambilla, C., Brambilla, E., Khochbin, S., 2013. Ectopic activation of germline and placental genes identifies aggressive metastasis-prone lung cancers. Sci Transl Med 5, 186ra66. doi:10.1126/scitranslmed.3005723

Sellier, Y., Galineau, J., Hulin, A., Caïni, F., Marquis, N., Navel, V., Bottagisi, S., GiorgisAllemand, L., Jacquier, C., Slama, R., Lepeule, J., EDEN Mother-Child Cohort Study Group, 2014. Health effects of ambient air pollution: do different methods for estimating exposure lead to different results? Environ Int 66, 165-173. doi:10.1016/j.envint.2014.02.001

Shah, A.S.V., Langrish, J.P., Nair, H., McAllister, D.A., Hunter, A.L., Donaldson, K., Newby, D.E., Mills, N.L., 2013. Global association of air pollution and heart failure: a systematic review and meta-analysis. Lancet 382, 1039-1048. doi:10.1016/S0140-6736(13)60898-3

Shen, L., Diao, Z., Sun, H.-X., Yan, G.-J., Wang, Z., Li, R.-T., Dai, Y., Wang, J., Li, J., Ding, H., Zhao, G., Zheng, M., Xue, P., Liu, M., Zhou, Y., Hu, Y., 2017. Up-regulation of CD81 inhibits cytotrophoblast invasion and mediates maternal endothelial cell dysfunction in preeclampsia. Proceedings of the National Academy of Sciences 114, 1940-1945. doi:10.1073/pnas.1617601114

Stieb, D.M., Chen, L., Eshoul, M., Judek, S., 2012. Ambient air pollution, birth weight and preterm birth: A systematic review and meta-analysis. Environ. Res. 117, 100-111. doi:10.1016/j.envres.2012.05.007

Šidák, Z., 1967. Rectangular Confidence Regions for the Means of Multivariate Normal Distributions. Journal of the American Statistical Association 62, 626-633. doi:10.1214/aoms/1177728724

Tobi, E.W., Lumey, L.H., Talens, R.P., Kremer, D., Putter, H., Stein, A.D., Slagboom, P.E., Heijmans, B.T., 2009. DNA methylation differences after exposure to prenatal famine are common and timing- and sex-specific. Human Molecular Genetics 18, 4046-4053. doi: $10.1093 / \mathrm{hmg} / \mathrm{ddp} 353$

Touleimat, N., Tost, J., 2012. Complete pipeline for Infinium ®Human Methylation 450K BeadChip data processing using subset quantile normalization for accurate DNA methylation estimation. Epigenomics 4, 325-341. doi:10.2217/epi.12.21

Valentino, S.A., Tarrade, A., Aioun, J., Mourier, E., Richard, C., Dahirel, M., Rousseau-Ralliard, D., Fournier, N., Aubrière, M.-C., Lallemand, M.-S., Camous, S., Guinot, M., Charlier, M., Aujean, E., Adhami, Al, H., Fokkens, P.H., Agier, L., Boere, J.A., Cassee, F.R., Slama, R., Chavatte-Palmer, P., 2015. Maternal exposure to diluted diesel engine exhaust alters placental function and induces intergenerational effects in rabbits. Part Fibre Toxicol 13, 39-39. doi:10.1186/s12989-016-0151-7 
van Iterson, M., van Zwet, E.W., BIOS Consortium, Heijmans, B.T., 2017. Controlling bias and inflation in epigenome- and transcriptome-wide association studies using the empirical null distribution. Genome Biol. 18, 19. doi:10.1186/s13059-016-1131-9

Wang, J., Mi, J.-Q., Debernardi, A., Vitte, A.-L., Emadali, A., Meyer, J.A., Charmpi, K., Ycart, B., Callanan, M.B., Carroll, W.L., Khochbin, S., Rousseaux, S., 2015. A six gene expression signature defines aggressive subtypes and predicts outcome in childhood and adult acute lymphoblastic leukemia. Oncotarget 6, 16527-16542. doi:10.18632/oncotarget.4113

Wick, P., Malek, A., Manser, P., Meili, D., Maeder-Althaus, X., Diener, L., Diener, P.-A., Zisch, A., Krug, H.F., Mandach, von, U., 2010. Barrier capacity of human placenta for nanosized materials. Environ. Health Perspect. 118, 432-436. doi:10.1289/ehp.0901200

World Health Organization, 2006. Air quality guidelines: global update 2005.

Yang, A.S., Estécio, M.R.H., Doshi, K., Kondo, Y., Tajara, E.H., Issa, J.-P.J., 2004. A simple method for estimating global DNA methylation using bisulfite PCR of repetitive DNA elements. Nucleic Acids Res. 32, e38. doi:10.1093/nar/gnh032

Yang, B.-Y., Qian, Z.M., Li, S., Fan, S., Chen, G., Syberg, K.M., Xian, H., Wang, S.-Q., Ma, H., Chen, D.-H., Yang, M., Liu, K.-K., Zeng, X.-W., Hu, L.-W., Guo, Y., Dong, G.-H., 2018. Long-term exposure to ambient air pollution (including PM1) and metabolic syndrome: The 33 Communities Chinese Health Study (33CCHS). Environ. Res. 164, 204-211. doi:10.1016/j.envres.2018.02.029

Zhao, W.-X., Huang, T.-T., Jiang, M., Feng, R., Lin, J.-H., 2014. Expression of notch family proteins in placentas from patients with early-onset severe preeclampsia. Reprod Sci 21, 716723. doi:10.1177/1933719113512530 